\title{
Red blood cells in sports: effects of exercise and training on oxygen supply by red blood cells
}

\author{
Heimo Mairbäurl * \\ Medical Clinic VII, Sports Medicine, University of Heidelberg, Heidelberg, Germany
}

\section{Edited by:}

Anna Bogdanova, University of

Zurich, Switzerland

Reviewed by:

Giovanni Lombardi, I.R.C.C.S.

Galeazzi Scientific Institute, Italy

Philippe Connes, UMR Inserm 665

Red Blood Cell Integrative Biology,

Guadeloupe

\section{*Correspondence:}

Heimo Mairbäurl, Medical Clinic VII, Sports Medicine, University of

Heidelberg, INF 410,

69120 Heidelberg, Germany

e-mail: heimo.mairbaeurl@

med.uni-heidelberg.de
During exercise the cardiovascular system has to warrant substrate supply to working muscle. The main function of red blood cells in exercise is the transport of $\mathrm{O}_{2}$ from the lungs to the tissues and the delivery of metabolically produced $\mathrm{CO}_{2}$ to the lungs for expiration. Hemoglobin also contributes to the blood's buffering capacity, and ATP and NO release from red blood cells contributes to vasodilation and improved blood flow to working muscle. These functions require adequate amounts of red blood cells in circulation. Trained athletes, particularly in endurance sports, have a decreased hematocrit, which is sometimes called "sports anemia." This is not anemia in a clinical sense, because athletes have in fact an increased total mass of red blood cells and hemoglobin in circulation relative to sedentary individuals. The slight decrease in hematocrit by training is brought about by an increased plasma volume (PV). The mechanisms that increase total red blood cell mass by training are not understood fully. Despite stimulated erythropoiesis, exercise can decrease the red blood cell mass by intravascular hemolysis mainly of senescent red blood cells, which is caused by mechanical rupture when red blood cells pass through capillaries in contracting muscles, and by compression of red cells e.g., in foot soles during running or in hand palms in weightlifters. Together, these adjustments cause a decrease in the average age of the population of circulating red blood cells in trained athletes. These younger red cells are characterized by improved oxygen release and deformability, both of which also improve tissue oxygen supply during exercise.

Keywords: $\mathrm{Hb}-\mathrm{O}_{2}$ affinity, blood gasses, 2,3-DPG, erythropoiesis, hypoxia inducible factor, ATP, NO, intravascular hemolysis

\section{INTRODUCTION}

The primary role of red blood cells is the transport of respiratory gasses. In the lung, oxygen $\left(\mathrm{O}_{2}\right)$ diffuses across the alveolar barrier from inspired air into blood, where the majority is bound by hemoglobin $(\mathrm{Hb})$ to form oxy- $\mathrm{Hb}$, a process called oxygenation. $\mathrm{Hb}$ is contained in the red blood cells, which, being circulated by the cardiovascular system, deliver $\mathrm{O}_{2}$ to the periphery where it is released from its $\mathrm{Hb}$-bond (deoxygenation) and diffuses into the cells. While passing peripheral capillaries, carbon dioxide $\left(\mathrm{CO}_{2}\right)$ produced by the cells reaches the red blood cells, where carbonic anhydrase (CA) in tissues and red blood cells converts a large portion of $\mathrm{CO}_{2}$ into bicarbonate $\left(\mathrm{HCO}_{3}^{-}\right) . \mathrm{CO}_{2}$ is also bound by $\mathrm{Hb}$, preferentially by deoxygenated $\mathrm{Hb}$ forming carboxy-bonds. Both forms of $\mathrm{CO}_{2}$ are delivered to the lung, where CA converts $\mathrm{HCO}_{3}^{-}$back into $\mathrm{CO}_{2}$. $\mathrm{CO}_{2}$ is also released from its bond to $\mathrm{Hb}$ and diffuses across the alveolar wall to be expired.

The biological significance of $\mathrm{O}_{2}$ transport by $\mathrm{Hb}$ is wellillustrated by anemia where decreased $\mathrm{Hb}$ also decreases exercise performance despite a compensatory increase in cardiac output (Ledingham, 1977; Carroll, 2007), and by improved aerobic performance upon increasing total $\mathrm{Hb}$ (Berglund and Hemmingson, 1987). The $\mathrm{O}_{2}$ dissociation curves in Figure 1 indicate the advantage of normal vs. anemic $\mathrm{Hb}$ showing that the $\mathrm{O}_{2}$ content in blood varies with the $\mathrm{Hb}$ concentration in blood at any given $\mathrm{O}_{2}$ partial pressure $\left(\mathrm{PO}_{2}\right)$. Not only its amount but also the functional properties of $\mathrm{Hb}$ affect performance. This is illustrated by the observation that an increased $\mathrm{Hb}-\mathrm{O}_{2}$ affinity favors $\mathrm{O}_{2}$ loading in the lung and survival in an hypoxic environment (Eaton et al., 1974; Hebbel et al., 1978), whereas a decreased $\mathrm{Hb}-\mathrm{O}_{2}$ affinity favors the release of $\mathrm{O}_{2}$ from the $\mathrm{Hb}$ molecule in support of oxidative phosphorylation when the ATP demand is high, such as in exercising skeletal muscle (for a recent review see Mairbäurl and Weber, 2012).

Despite $\mathrm{O}_{2}$ transport, red blood cells fulfill a variety of other functions, all of which also may improve exercise performance. Likely the most important one is the contribution of red blood cells in buffering changes in blood $\mathrm{pH}$ by transport of $\mathrm{CO}_{2}$ and by binding of $\mathrm{H}^{+}$to hemoglobin. Red blood cells also take up metabolites such as lactate that is released from skeletal muscle cells during high intensity exercise. Uptake into red blood cells decreases the plasma concentration of metabolites. Finally, red blood cells seem to be able to decrease peripheral vascular resistance by releasing the vasodilator NO (Stamler et al., 1997) and by releasing ATP which stimulates endothelial NO formation causing arteriolar vasodilation and augments local blood flow (Gonzalez-Alonso et al., 2002).

This review summarizes the mechanisms by which red blood cells warrant $\mathrm{O}_{2}$ supply to the tissues with special emphasis on $\mathrm{O}_{2}$ transport to exercising muscle. 


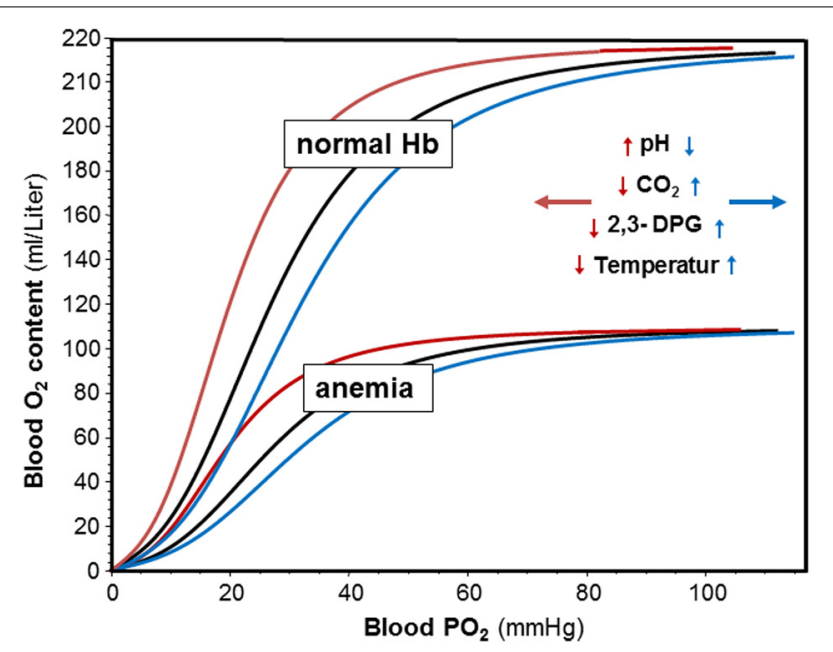

FIGURE 1 | Effects of hemoglobin concentration and $\mathrm{pH}, \mathrm{CO}_{2}$, 2,3-DPG and temperature on blood oxygen content and on $\mathrm{Hb}-\mathrm{O}_{2}$ affinity. Oxygen dissociation curves (ODC) were calculated with the equation by Severinghaus (1979) using decreased, normal, and increased $P_{50}$ values. Oxygen content was calculated from $\mathrm{SO}_{2}$ and normal and decreased hemoglobin concentrations assuming that $1 \mathrm{~g} \mathrm{H}$ binds $1.34 \mathrm{ml}$ of $\mathrm{O}_{2}$. The insert indicates that an increase in $\mathrm{pH}$, and a decrease in $\mathrm{CO}_{2}, 2,3-\mathrm{DPG}$ and temperature shifts the ODC to the left (red arrows and curves), whereas acidosis and increased $\mathrm{CO}_{2}, 2,3-\mathrm{DPG}$ and temperature shift the ODCs to the right.

\section{OXYGEN AFFINITY OF HEMOGLOBIN}

A major mechanism optimizing $\mathrm{O}_{2}$ transport by hemoglobin is the change in $\mathrm{Hb}-\mathrm{O}_{2}$ affinity. Changes are very fast and actually occur while red blood cells pass through blood capillaries. Effects of altered $\mathrm{Hb}-\mathrm{O}_{2}$ affinity on $\mathrm{O}_{2}$ transport are independent of $\mathrm{Hb}$ concentration and total $\mathrm{Hb}$ mass in circulation and thus add to the adjustment by changes in erythropoiesis.

The intrinsic $\mathrm{O}_{2}$-affinity of hemoglobin is very high (Weber and Fago, 2004). Therefore, allosteric effectors are required that decrease $\mathrm{Hb}-\mathrm{O}_{2}$ affinity allowing unloading of $\mathrm{O}_{2}$ from the $\mathrm{Hb}$ molecule. The major allosteric effectors modulating $\mathrm{Hb}-\mathrm{O}_{2}$ affinity in vivo in human red blood cells are organic phosphates such as 2,3-diphosphoglycerate (2,3-DPG) and adenosine triphosphate (ATP), $\mathrm{H}^{+}$and $\mathrm{CO}_{2}$, and $\mathrm{Cl}^{-}$. A direct role of lactate, which accumulates during exercise, on $\mathrm{Hb}-\mathrm{O}_{2}$-affinity is less clear and may be due to a small effect on the $\mathrm{Cl}^{-}$binding by $\mathrm{Hb}$ and on carbamate formation (reviewed in (Mairbäurl and Weber, 2012)). Indirect effects of lactate may be caused by affecting the $\mathrm{Cl}^{-}$ concentration and by the uptake of $\mathrm{H}^{+}$together with lactate mediated by MCT-1 (Deuticke, 1982). Another modulator of Hb$\mathrm{O}_{2}$ affinity relevant to exercise is a change in body temperature (Dill and Forbes, 1941; Mairbäurl and Humpeler, 1980). Figure 1 shows that at any $\mathrm{Hb}$ concentration, acidosis, and an increase in $\mathrm{CO}_{2}$ and 2,3-DPG decrease $\mathrm{Hb}-\mathrm{O}_{2}$ affinity. Changes in $\mathrm{Cl}^{-}$are small in vivo and are therefore not shown on the graph. Also an increase in temperature decreases $\mathrm{Hb}-\mathrm{O}_{2}$ affinity. These changes shift the ODC to the right showing graphically that the $\mathrm{O}_{2}$ saturation of $\mathrm{Hb}\left(\mathrm{SO}_{2}\right)$ is decreased at any given $\mathrm{PO}_{2}$. In contrast, alkalosis, a decrease in $\mathrm{CO}_{2}, 2,3-\mathrm{DPG}$, and temperature increase $\mathrm{Hb}-\mathrm{O}_{2}$ affinity to increase $\mathrm{SO}_{2}$ at a given $\mathrm{PO}_{2}$.
The physiological significance of an increased $\mathrm{Hb}-\mathrm{O}_{2}$ affinity is an improved $\mathrm{O}_{2}$ binding by $\mathrm{Hb}$ when the $\mathrm{PO}_{2}$ is low. It is therefore of significance for people exposed to hypoxic environments, where it prevents exaggerated arterial desaturation. A decrease in $\mathrm{Hb}-\mathrm{O}_{2}$ affinity improves $\mathrm{O}_{2}$ delivery to cells with a high $\mathrm{O}_{2}$ demand such as in exercising muscle (see below).

A simple approach to estimate the $\mathrm{SO}_{2}$ from $\mathrm{PO}_{2}$ and vice versa has been published by Severinghaus (1979). The formula was derived from a best fit model of the standard oxygen dissociation curve with an error of $\mathrm{SO}_{2}$ of $0.26 \%$ within the physiological range of $\mathrm{PO}_{2}$. The standard half saturation pressure of $\mathrm{O}_{2}$ ( $\mathrm{P}_{50}$ value) was given as $26.86 \mathrm{mmHg}$ at a plasma $\mathrm{pH}=7.4$ and $37^{\circ} \mathrm{C}$; $\mathrm{S}$ is fractional saturation.

$$
\begin{aligned}
\mathrm{S} & =100 \times\left(\left(\left(\mathrm{PO}_{2}^{3}+150 \times \mathrm{PO}_{2}\right)^{-1} \times 23400\right)+1\right)^{-1} \text { or } \\
\ln \mathrm{PO}_{2, \mathrm{st}} & =0.385 \times \ln \left(\mathrm{S}^{-1}-1\right)+3.32-(72 \times \mathrm{S})^{-1}-0.17 \times \mathrm{S}^{6}
\end{aligned}
$$

Based on a model proposed by Roughton and Severinghaus (1973), Okada et al. (1977) published a modification of this formula that allows estimating changes in $\mathrm{P}_{50}$ by altered $\mathrm{pH}$, temperature $\left(\mathrm{T} ;{ }^{\circ} \mathrm{C}\right)$, base excess $(\mathrm{BE} ; \mathrm{mEq} / \mathrm{Liter})$, and 2,3-DPG (DPG; molar ration of 2,3-DPG to $\mathrm{Hb}$ ) with accuracies of $\mathrm{P}_{50}$ values and $\mathrm{SO}_{2}$ of \pm 2.5 and $\pm 5 \%$, respectively.

$$
\begin{aligned}
\Delta \log _{50}= & 0.48 \times\left(7.4-\mathrm{pH}_{\text {plasma }}\right)+0.024 \times(\mathrm{T}-37) \\
& +0.0013 \times \mathrm{BE}+0.135 \times \mathrm{DPG}-0.116
\end{aligned}
$$

After correction of $\mathrm{P}_{50}$ using this equation to obtain $\mathrm{P}_{50 \text {,actual, }}$ adjusted $\mathrm{PO}_{2}\left(\mathrm{PO}_{2}\right.$, actual $)$ values can be calculated (Severinghaus, 1979) as

$$
\mathrm{PO}_{2, \text { actual }}=\mathrm{PO}_{2, \text { std }} \times \frac{\mathrm{P}_{50, \text { actual }}}{26.86}
$$

Then the "Severinhaus-equation" can be used to calculate $S$ from the new $\mathrm{PO}_{2}$ to obtain complete ODCs. A more detailed description of the magnitude of changes in $\mathrm{Hb}-\mathrm{O}_{2}$ affinity by allosteric effectors, temperature, and other molecules alone as well as their interactions is reviewed in (Mairbäurl and Weber, 2012).

\section{$\mathrm{Hb}^{-\mathrm{O}_{2}}$ AFFINITY DURING EXERCISE}

During exercise the increased demand for oxygen is met by increasing muscle blood flow (Laughlin et al., 2012) and by improved $\mathrm{O}_{2}$ unloading from $\mathrm{Hb}$ achieved by decreasing $\mathrm{Hb}-\mathrm{O}_{2}$ affinity (Mairbäurl, 1994). It is obvious that a decreased $\mathrm{Hb}-\mathrm{O}_{2}$ affinity, if occurring systemically-i.e., in all red blood cells in circulation-will compromise arterial $\mathrm{O}_{2}$ loading of $\mathrm{Hb}$ in the lung. It would thus be advantageous if adjustments in $\mathrm{Hb}-\mathrm{O}_{2}$ affinity occurred locally to serve both functions, oxygenation in the lung and deoxygenation in peripheral blood capillaries. Thus, $\mathrm{Hb}-\mathrm{O}_{2}$ affinity should be low while red blood cells pass through tissues with a high $\mathrm{O}_{2}$ demand, and should be increased when red blood cells return to the lung. This is in fact what happens because of distinct differences in $\mathrm{pH}, \mathrm{CO}_{2}$ and temperature between the lung and capillaries in working muscles. No changes in 2,3-DPG, one of the major allosteric effectors of $\mathrm{Hb}-\mathrm{O}_{2}$ affinity (Benesch and Benesch, 1967), during exercise tests have been 
observed (Mairbäurl et al., 1986), because 2,3-DPG changes are slow and require adjustments of the glycolytic rate in red blood cells. However, elevated 2,3-DPG has been found after training (Böning et al., 1975; Braumann et al., 1982; Mairbäurl et al., 1983; Schmidt et al., 1988). It might be considered beneficial for $\mathrm{O}_{2}$ unloading during exercise because it increases the effect of acidosis (Bohr effect) on $\mathrm{Hb}-\mathrm{O}_{2}$ affinity (Bauer, 1969). The elevated 2,3-DPG in trained individuals might be a consequence of the stimulated erythropoiesis, which decreases red blood cell age (Mairbäurl et al., 1983). Young red blood cells have an increased metabolic activity (Seamen et al., 1980; Rapoport, 1986), higher 2,3-DPG, and a lower Hb-O2-affibity than senescent red blood cells (Haidas et al., 1971; Mairbäurl et al., 1990).

\section{$\mathrm{O}_{2}$ unloading to exercising muscle}

Exercising muscle cells release $\mathrm{H}^{+}, \mathrm{CO}_{2}$, and lactate into blood capillaries, and there is also a higher temperature in working muscle than in inactive tissues. Blood entering capillaries of exercising muscles is acutely exposed to these changes, which causes a rapid decrease in $\mathrm{Hb}-\mathrm{O}_{2}$ affinity. $\mathrm{P}_{50}$ values of $\sim 34-48 \mathrm{mmHg}$ can be estimated from changes in blood gasses (provided e.g., in Sun et al., 2000). Temperature increases from $37^{\circ} \mathrm{C}$ at rest to $41^{\circ} \mathrm{C}$ during exercise. Because there is a continuous change in blood composition by admixture of metabolites as new blood enters a capillary, $\mathrm{P}_{50}$ values are lower at the arterial side of the capillaries than at their venous end (Mairbäurl and Weber, 2012) causing an enormous rightward shift of the ODC within the capillaries that increases unloading of $\mathrm{O}_{2}$ from $\mathrm{Hb}$ considerably (Berlin et al., 2002). This is also demonstrated by the extensive shift to the right of the ODC in capillary blood in exercise conditions relative to rest (Figure 2; points D and B, respectively). Trained individuals

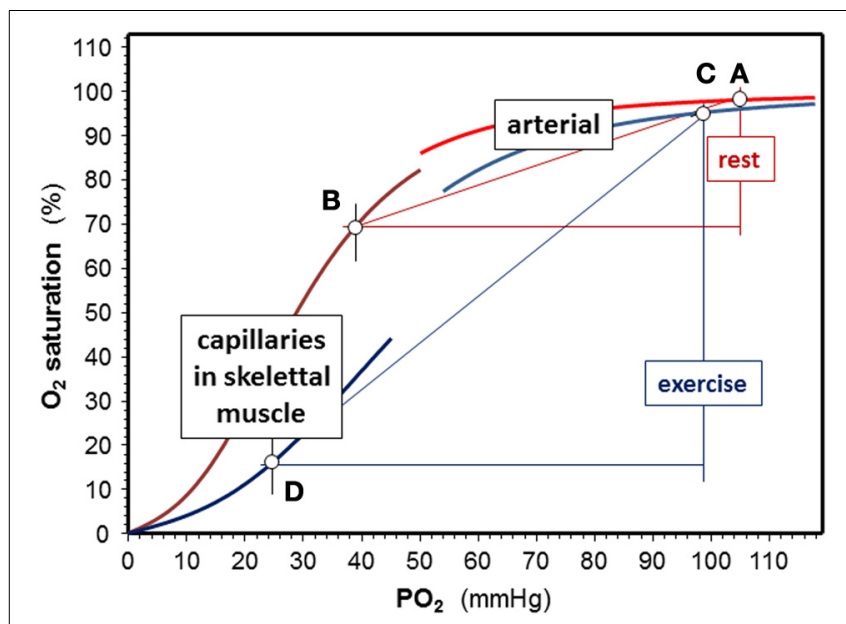

FIGURE 2 | Effects of exercise on $\mathbf{H b}-\mathbf{O}_{2}$ affinity. Shifts of the $\mathrm{O}_{2}$-dissociation curves are calculated for an arterial $\mathrm{pH}=7.4$, a capillary $\mathrm{pH}$ $=7.3$, and temperature is $37^{\circ} \mathrm{C}$ rest. Values used to calculate oxygen dissociation curves (ODC) for exercise were an arterial $\mathrm{pH}=7.15$ at $38.5^{\circ} \mathrm{C}$, a capillary $\mathrm{pH}=7.0$ and temperature $=41^{\circ} \mathrm{C}$ in working muscle using the equation giving in the text using data from exercise tests (Sun et al., 2000). At rest, assuming a venous $\mathrm{PO}_{2}=40 \mathrm{mmHg}, \mathrm{SO}_{2}$ decreases by $28 \%$ (points $\mathbf{A}$ and $\mathbf{B}$ ), while extraction nearly triples in exercise conditions (delta $\mathrm{SO}_{2}=79 \%$ ) assuming a venous $\mathrm{PO}_{2}=25 \mathrm{mmHg}$ during exercise (points $\mathbf{C}$ and D). have a higher Bohr effect at low $\mathrm{SO}_{2}$ probably due to elevated 2,3-DPG (Böning et al., 1975; Braumann et al., 1982; Mairbäurl et al., 1983), which might cause an even greater increase in the arterio-to-venous $\mathrm{O}_{2}$ difference.

\section{Arterial $\mathrm{O}_{2}$ loading}

On its way from working muscle to the lung the concentrations of $\mathrm{H}^{+}$and $\mathrm{CO}_{2}$ in blood are decreased by admixture of blood coming from inactive muscle and other organs. $\mathrm{CO}_{2}$ decreases in alveolar capillaries due to alveolar gas exchange, which further alkalinizes the blood. Thus, the effects of these metabolites on $\mathrm{Hb}-\mathrm{O}_{2}$ affinity are attenuated in the lung relative to working muscle. Also the temperature is lower in the lung than in working muscle. Nevertheless, normal values of $\mathrm{Hb}-\mathrm{O}_{2}$ affinity are not restored completely during intensive exercise, which is indicated by the slight shift to the right of the ODC in the exercise conditions relative to the resting situation (Figure 2; points A and $\mathrm{C})$. The magnitude of the deviation depends on the active muscle mass and exercise intensity. From blood gas data during exercise reported by Wasserman and colleagues (Sun et al., 2000) it can be estimated that the half saturation tension of $\mathrm{O}_{2}$ ( $\mathrm{P}_{50}$ value) might increase from about $\sim 27 \mathrm{mmHg}$ at rest to $34 \mathrm{mmHg}$ in arterial blood during heavy exercise. This decrease in $\mathrm{Hb}-\mathrm{O}_{2}$ affinity impairs arterial $\mathrm{O}_{2}$ loading and decreases arterial $\mathrm{SO}_{2}$ from $\sim 97.5 \%$ at rest to $\sim 95 \%$ during high intensity exercise. An increased 2,3-DPG in trained individuals might further decrease arterial $\mathrm{SO}_{2}$ (Mairbäurl et al., 1983). Adding to the effect of decreased $\mathrm{Hb}-\mathrm{O}_{2}$ affinity, $\mathrm{SO}_{2}$ decreases further because of diffusion limitation by the shortened contact time when cardiac output is high (Dempsey and Wagner, 1999; Hopkins, 2006), which might even be enhanced when exercise is performed in hypoxia (Calbet et al., 2008).

When comparing the effects of acid metabolites and the increased body temperature during exercise on $\mathrm{Hb}-\mathrm{O}_{2}$ affinity in arterial and muscle capillary blood it is evident that the changes are much greater in working muscle than in the lung. Thus, the greatly increased amount of $\mathrm{O}_{2}$ unloaded from $\mathrm{Hb}$ relative to rest easily compensates for arterial desaturation during exercise.

\section{OXYGEN TRANSPORT CAPACITY}

Whereas only $0.03 \mathrm{ml} \mathrm{O}_{2} * \mathrm{~L}^{-1} * \mathrm{mmHg}^{-1} \mathrm{PO}_{2}$ at $37^{\circ} \mathrm{C}$ can be transported in blood in physical solution, one gram of $\mathrm{Hb}$ can bind $\sim 1.34 \mathrm{ml}$ of $\mathrm{O}_{2}$. Thus, the presence of a normal amount of $\mathrm{Hb}$ per volume of blood increases the amount of $\mathrm{O}_{2}$ that can be transported about 70-fold, which is absolutely essential to meet the normal tissue $\mathrm{O}_{2}$ demand. It is therefore apparent that an increased amount of $\mathrm{Hb}$ also increases the amount of $\mathrm{O}_{2}$ that can be delivered to the tissues (Figure 1). In fact, the $\mathrm{O}_{2}$ transport capacity was found to correlate directly with aerobic performance as can be seen from an increase in performance after infusion of red blood cells (Berglund and Hemmingson, 1987) and by the strong correlation between total $\mathrm{Hb}$ and maximal $\mathrm{O}_{2}$ uptake $\left(\mathrm{VO}_{2, \max }\right)$ in athletes (for review see Sawka et al., 2000; Schmidt and Prommer, 2010). Calbet et al found that acute manipulations of the $\mathrm{O}_{2}$ carrying capacity also vary performance (Calbet et al., 2006). Thus, it is a clear advantage for aerobic athletic performance to have a high $\mathrm{O}_{2}$ transport capacity. 
Parameters required to evaluate $\mathrm{O}_{2}$ transport capacity are the $\mathrm{Hb}$ concentration in blood ( $\mathrm{cHb}$ ) and hematocrit (Hct), as well as total $\mathrm{Hb}$ mass $(\mathrm{tHb})$ and total red blood cell volume (tEV) in circulation. $\mathrm{cHb}$ and Hct are easy to measure with standard hematological laboratory equipment. Together with $\mathrm{SO}_{2}$ they indicate the amount of $\mathrm{O}_{2}$ that can be delivered to the periphery per unit volume of cardiac output. $\mathrm{tHb}$ and $\mathrm{tEV}$ indicate the total amount of $\mathrm{O}_{2}$ that can be transported by blood. A large $\mathrm{tHb}$ and $\mathrm{tEV}$ allows redirecting $\mathrm{O}_{2}$ to organs with a high $\mathrm{O}_{2}$ demand while maintaining basal $\mathrm{O}_{2}$ supply in less active tissues. Because they are affected by changes in plasma volume (PV) $\mathrm{cHb}$ and Hct allow no conclusion on $\mathrm{tHb}$ and $\mathrm{tEV}$, respectively.

Results on $\mathrm{cHb}$, Hct and red blood cell count in athletes and their comparison with values obtained in healthy, sedentary individuals are conflicting due to the fact that red blood cell volume and PV change independently and due to the many factors affecting each of these parameters (see below). Establishing normal values for $\mathrm{tHb}$ and $\mathrm{tEV}$ for athletes is hampered further by the possibility of use of means to increase aerobic capacity such as blood and erythropoietin (EPO) doping.

\section{HEMATOCRIT IN ATHLETES}

Many but not all studies show lower Hct in athletes than in sedentary controls (Broun, 1922; Davies and Brewer, 1935; Ernst, 1987; Sawka et al., 2000). However, several studies also report higher than normal Hct. A highly increased Hct increases blood viscosity and increases the workload of the heart (El-Sayed et al., 2005; Böning et al., 2011). It therefore bears the risk of cardiac overload.

Many studies showed that Hct tended to be lower in athletes than in sedentary individuals (Broun, 1922; Davies and Brewer, 1935; Remes, 1979; Magnusson et al., 1984; Selby and Eichner, 1986; Ernst, 1987; Weight et al., 1992). This was verified by Sharpe et al. (2002) in the course of establishing reference Hct and $\mathrm{Hb}$ values for athletes. The found that out of $\sim 1100$ athletes from different countries $85 \%$ of the female and $22 \%$ of the male athletes had Hct values below 44\%. A tendency for an inverse correlation of Hct with training status, indicated by $\mathrm{VO}_{2, \max }$, was also shown (Heinicke et al., 2001). However, a small proportion of sedentary controls and athletes has higher than normal Hct. Sharpe et al. (2002) found that $1.2 \%$ of all females and $32 \%$ of all males in their study had an Hct $>47 \%$. When following female and male elite athletes and controls over a study period of 43 months Vergouwen (Vergouwen et al., 1999) found 6 males controls and 5 males athletes with a Hct $>50 \%$ and 5 females controls but no female athletes with a Hct $>47 \%$.

\section{Hematocrit during exercise}

Changes in Hct occur rapidly. Hct increases during exercise due to a decrease in PV when fluid replacement during exercise is insufficient (Costill et al., 1974). There is fluid loss due to sweating, a shift of plasma water into the extracellular space due to the accumulation of osmotically active metabolites, and filtration as a consequence of an increased capillary hydrostatic pressure (Convertino, 1987). The resultant increase in plasma protein increases oncotic pressure and thus moderates fluid escape (Harrison, 1985). Changes appear less pronounced during swimming than running exercise, where immersion and the re-distribution of blood volume seem to cause shifts in PV independent of volume regulatory hormones (Böning et al., 1988). An increase in hematocrit due to catecholamine-induced sequestration of red blood cells from spleen is unlikely in humans but has been found in other species (Stewart and McKenzie, 2002).

\section{Long-term changes of hematocrit}

In a recent review, Thirup (2003) reports a within-subject variability of $\sim 3 \%$ when reviewing 12 studies on more than 600 healthy, non-smoking, mostly sedentary individuals, and when measurements were repeated in sampling intervals ranging from days to $\sim 2$ months. Sawka et al. summarized data from 18 investigations and found that $\mathrm{PV}$ and blood volume increased rapidly after training sessions, whereas red cell volume remained unchanged for several days before it began to increase indicating that Hct values were decreased for several days (Sawka et al., 2000). The magnitude of Hct change seems to depend on exercise intensity during training sessions and the type of exercise (strength vs. endurance; for review see $\mathrm{Hu}$ and Lin, 2012). A few weeks after the training intervention a new steady state had established, and Hct had returned to pre-training values (Sawka et al., 2000). The post-training increase in PV and the increased PV in highly trained athletes (e.g., Hagberg et al., 1998; Sawka et al., 2000; Heinicke et al., 2001; Schumacher et al., 2002) is likely caused by aldosterone dependent renal $\mathrm{Na}^{+}$reabsorption, and by water retention stimulated by elevated antidiuretic hormone in compensation for the water loss during individual training sessions (Costill et al., 1976; Milledge et al., 1982).

There appear to be quite large seasonal variations in Hct (relative change up to $15 \%$ ) with lower values in summer than in winter that might result in season-to-season changes from $\sim 42 \%$ in summer and $48 \%$ in winter as found among several thousand study participants. Seasonal changes depend on climatic effects with larger differences in countries closer to the equator (Thirup, 2003). Studies of seasonal changes in Hct of athletes are sparse but indicate that Hct might be decreased by another 1-2\% in summer by addition of a training effect.

The decreased Hct in athletes has been termed "sports anemia." For a long time it had been explained with increased red blood cell destruction during exercise and thus appeared to be the same phenomenon as the well-known march hemoglobinuria (Broun, 1922; Kurz, 1948; Martin and Kilian, 1959). Intravascular destruction of red blood cells occurs at shear stresses between 1000 and $4000 \mathrm{dyn} / \mathrm{cm}^{2}$ (Sutera, 1977; Sallam and Hwang, 1984), values well above physiological values at rest (Mairbäurl et al., 2013). It is related to the intensity and the kind of exercise (Yoshimura et al., 1980; Miller et al., 1988). Foot strike in runners has been the most often reported reason for intravascular hemolysis (Telford et al., 2003), which can be prevented by good shoe cushioning (Yoshimura et al., 1980; Dressendorfer et al., 1992). It also occurred during mountain hiking (Martin et al., 1992), in strength training (Schobersberger et al., 1990), karate (Streeton, 1967), in swimmers (Selby and Eichner, 1986; Robinson et al., 2006), basketball, Kendo-fencing, and in drummers (Schwartz and Flessa, 1973; Nakatsuji et al., 1978). Running exercise has been found to increase plasma hemoglobin from $\sim 30 \mathrm{mg} / \mathrm{liter}$ at 
rest to $\sim 120 \mathrm{mg} /$ liter indicating that about $0.04 \%$ of all circulating red blood cells were lyzed (Telford et al., 2003). Exercise had been shown to alter red blood cell membrane appearance in correlation with elevated haptoglobin (Jordan et al., 1998). Senescent red blood cells may be particularly prone to exercise induced intravascular hemolysis as indicated by a decreased mean red blood cell buoyant density and a density distribution curve that was skewed toward younger, less dense cells in trained individuals indicated by increased levels of pyruvate kinase activity, 2,3-DPG and $\mathrm{P}_{50}$, higher reticulocyte counts (Mairbäurl et al., 1983). Other possible reasons for "sports anemia" under discussion are nutritional aspects such as insufficient protein intake and altered profile of blood lipids (for review see Yoshimura et al., 1980), and iron deficiency (Hunding et al., 1981).

\section{TOTAL HEMOGLOBIN MASS (tHb) AND TOTAL RED BLOOD CELL VOLUME (tEV)}

As indicated above, $\mathrm{PV}$ is prone to acute changes, whereas changes in total red blood cell mass (or volume) are slow due to slow rates of erythropoiesis (Sawka et al., 2000). Therefore, total hemoglobin and/or red blood cell volume has to be measured in addition to $\mathrm{cHb}$ and Hct to obtain a reliable measure of the oxygen transport capacity. Several methods have been applied to determine these parameters.

Grehant and Quinquard (1882) were the first to describe blood volume measurements by use of carbon monoxide (CO)rebreathing. This method is based on the much higher affinity of $\mathrm{Hb}$ to $\mathrm{CO}$ than to $\mathrm{O}_{2}$ (for review see Mairbäurl and Weber, 2012), which allows using $\mathrm{CO}$ in an indicator dilution method. It has been used to measure the fraction of blood mass relative to body mass by Arnold et al. (1921). The technique has been improved considerably by Sjostrand by advancing the method to estimate carboxy-hemoglobin (Sjostrand, 1948). To date CO rebreathing or inhalation has been further improved (Godin and Shephard, 1972; Schmidt and Prommer, 2005). MCHC is then used to calculate $\mathrm{tEV}$, and Hct to estimate total blood volume. Total red blood cell volume can be determined directly after injection of ${ }^{99} \mathrm{~m} \mathrm{Tc}$ labeled red blood cells (Thomsen et al., 1991). By indirect means, total red blood cell volume can also be calculated from Hct after measuring the PV using Evans blue (T-1824), which binds to albumin, and by injection of ${ }^{125}$ iodine-labeled albumin. Several of these methods have been compared by Thomsen et al. (1991) who reported a correlation of $r=0.99$ between PV measured by ${ }^{125} \mathrm{I}$-albumin and Evans blue, and showed that PV calculated from measuring tEV with labeled red blood cells was about 5-10\% lower than that from labeling albumin.

Applying these techniques Kjellberg et al. found that trained individuals had increased tHb (Kjellberg et al., 1949), a result that has been confirmed many times thereafter both by comparing groups of individuals with different training status and by measuring tEV before and after prolonged training periods (for a recent review see Sawka et al., 2000). Schmidt and Prommer summarized recently that different training modalities vary in their effects on $\mathrm{tHb}$, where they put the main emphasis on training in hypoxia (Schmidt and Prommer, 2008). In summary, these studies show that an increase in $\mathrm{tHb}$ by $1 \mathrm{~g}$ achieved e.g., by administration of erythropoietin, increased $\mathrm{VO}_{2, \max }$ by $\sim 3 \mathrm{ml} / \mathrm{min}$ (Parisotto et al., 2000; Schmidt and Prommer, 2008). From the correlation shown by Heinicke et al. (2001) it can be derived that an increase in $1 \mathrm{~g}$ of $\mathrm{tHb}$ per $\mathrm{kg}$ body weight ( $\mathrm{g} / \mathrm{kg}$ ) increased $\mathrm{VO}_{2 \text {, } \max }$ by $\sim 5.8 \mathrm{ml} / \mathrm{min} / \mathrm{kg}$, where non-athletes (though with a rather high $\mathrm{VO}_{2, \max }$ of $45 \mathrm{ml} / \mathrm{min} / \mathrm{kg}$ ) had a $\mathrm{tHb}$ of $11 \mathrm{~g} / \mathrm{kg}$ and their best athletes (average $\mathrm{VO}_{2, \max }=71.9 \mathrm{ml} / \mathrm{kg}$ ) had a tHb of $14.8 \mathrm{~g} / \mathrm{kg}$ (Heinicke et al., 2001). Their findings fit well to the results reported by Kjellberg, who found a 37\% higher $\mathrm{tHb}$ in elite athletes than in untrained individuals (Kjellberg et al., 1949). Schmidt and Prommer (2008) combined results from several of their studies and found a change in $\mathrm{VO}_{2, \max }$ of $4.2 \mathrm{ml} / \mathrm{min} / \mathrm{kg}$ in males and of $4.4 \mathrm{ml} / \mathrm{min} / \mathrm{kg}$ in females per change in $\mathrm{tHb}$ of $1 \mathrm{~g} / \mathrm{kg}$ with very high correlation coefficients $(r \sim 0.79)$, whereas there was no correlation between $\mathrm{VO}_{2, \max }$ and $\mathrm{Hb}$ or Hct. However, there are also reports on a lack of difference in $\mathrm{tHb}$ between sedentary and trained individuals (Green et al., 1991). As mentioned above all these studies bear the burden of uncertainty that athletes may have taken measures to increase performance, which makes it difficult to establish "normal values" of $\mathrm{tHb}$ and $\mathrm{tEV}$ for athletes.

Different duration of exercise training (weeks vs. months) appear to explain the diverging results in the studies on $\mathrm{tHb}$ and training. Sawka et al. (2000) found no increase when training lasted less than 11 days. Also most studies on 4-12 months of training showed no or only small effects; their own longitudinal study on "leisure sportsmen" resulted in an increase in $\mathrm{tHb}$ by $\sim 6 \%$ in the course of a 9 -month endurance training (summarized in Schmidt and Prommer, 2008) indicating that adjustments of $\mathrm{tHb}$ and $\mathrm{tEV}$ by training are slow, and that a pronounced increase may require several years of training.

Sedentary high altitude residents have an increased $\mathrm{tHb}$ in comparison to their low altitude counterparts, where blood volume has been found to be increased from $\sim 80$ to $\sim 100 \mathrm{ml} / \mathrm{kg}$ (Hurtado, 1964; Sanchez et al., 1970). Results on sojourners to high altitude indicate that, similar to training, the increase in $\mathrm{tHb}$ and blood volume is also slow requiring weeks to months of high altitude exposure. At high altitude, the increase may be masked by a decrease in PV (Reynafarje et al., 1959). Therefore, a short-term stay at moderate and high altitude will not increase tHb and tEV (Myhre et al., 1970). A summary of 14 different studies Sawka et al. (2000) shows that several studies found no change in tEV upon ascent whereas some did, and explained discrepancies with the difference in the duration of exposure to high altitude. A gain in tEV between 62 and $250 \mathrm{ml} /$ week was found when the sojourn lasted about 3 weeks.

Based on the raise in $\mathrm{tEV}$ upon ascent to high altitude and by training in normoxia it was concluded that effects of training and high altitude exposure on $\mathrm{tHb}$ might be additive, and that training at simulated altitude or by ascent to moderate or high altitude should cause an even further increase than training in normoxia. However, results are inconsistent ranging from no effect (Svedenhag et al., 1997; Friedmann et al., 1999) to a pronounced increase after 3-4 weeks of training at altitudes between 2100 and $2400 \mathrm{~m}$ (Levine and Stray-Gundersen, 1997; Friedmann et al., 2005; Heinicke et al., 2005). Lack of effects has in part been explained with lower training intensities at high than at low altitude, which is due to the decrease in performance with 
increasing altitude (Cerretelli and DiPrampero, 1985). Several strategies have been developed aimed at improving the training efficiency while still "consuming" adjustments to hypoxia, one being the "sleep-high-train-low" protocol. Current concepts and concerns are reviewed in (Richalet and Gore, 2008; StrayGundersen and Levine, 2008; Robach and Lundby, 2012). Results are unclear, and often show no effect on tHb [e.g., in a welldesigned, Placebo-controlled study by Siebenmann et al. (2012)]. A thorough analysis reveals that more than $14 \mathrm{~h}$ per day of exposure to hypoxia seem to be required to attain a detectible increase in tHb and tEV (analysis in Schmidt and Prommer, 2008).

\section{Control of erythropoiesis}

It has been recognized by Bert (1882) that live at high altitude corresponds with increased hemoglobin, and later that $\mathrm{Hct}, \mathrm{Hb}$, and $\mathrm{tHb}$ are increased (Reynafarje et al., 1959; Hurtado, 1964; Sanchez et al., 1970), which was later recognized to be associated with elevated levels of erythropoietin (Mirand and Prentice, 1957; Scaro, 1960; Siri et al., 1966). The elevated tEV is thought to compensate for the decreased arterial $\mathrm{O}_{2}$-content when the inspired $\mathrm{PO}_{2}$ is low. Stimulation of vascularization by the vascular endothelial growth factor, VEGF, is another means warranting tissue $\mathrm{O}_{2}$ supply in chronic hypoxia (for review see e.g., Marti, 2005). Both processes depend on sensing hypoxia within typical target cells and specific signaling pathways that adjust the expression of specific genes.

One such oxygen dependent mechanism is the control of expression by hypoxia inducible factors, HIF (Semenza, 2009). Active HIF consists of alpha and beta subunits. The beta subunit (HIF- $\beta$, also called ARNT) is expressed constitutively and is not directly affected by oxygen levels (Semenza, 1999). There are several isoforms of the alpha subunit, where HIF- $1 \alpha$ seems to mainly control metabolic adjustments such as glycolysis ( $\mathrm{Hu}$ et al., 2003), and HIF-2 $\alpha$ has been identified as the major regulator of erythropoiesis (Scortegagna et al., 2005; Gruber et al., 2007). In hypoxia, the hydroxylation of HIF-alpha subunits by prolyl-hydroxylases ( $\mathrm{PDH})$ is prevented due to the lack of $\mathrm{O}_{2}$ required as a direct substrate, which then prevents the hydroxylation-dependent poly-ubiquitinylation by the Van Hippel-Lindau tumor suppressor pVHL-E3 ligase and subsequent proteasomal degradation (Schofield and Ratcliffe, 2004) resulting in increased protein levels of HIF alpha subunits. Upon stabilization, alpha subunits enter the nucleus, where they dimerize with HIF- $\beta$. The dimer binds to a specific base sequence in the promoter region of genes called hypoxia response element, HRE, to induce the expression of genes (for recent reviews see (Semenza, 2009; Haase, 2010)). Besides stabilization, HIF-alpha subunits are also controlled at the transcriptional level (Görlach, 2009; Semenza, 2009).

In his review Haase (2010) nicely summarizes the experiments that led to the conclusion that HIF- $2 \alpha$ is the major regulator of EPO production in liver (fetal) and kidney (adults), but that there are also a variety of different direct and indirect mechanisms. As shown in the scheme provided by Semenza (2009), although at that time related to actions of HIF- $1 \alpha$ rather than HIF- $2 \alpha$, it can be seen that hypoxia controlled gene expression regulates not only the expression of EPO but also the expression of proteins whose action is a prerequisite for erythropoiesis such as EPO-receptors, iron transporters mediating intestinal iron reabsorption, and transferrin and transferrin receptors required for iron delivery to peripheral cells.

In the adult, the oxygen sensor controlling EPO production is in the kidney, where the cells producing EPO have been shown to be peritubular fibroblasts in the renal cortex (Maxwell et al., 1993; Eckardt and Kurtz, 2005). EPO production can be induced by two kinds of hypoxia: one is a decreased $\mathrm{PO}_{2}$ in the kidney and in other tissues while the hemoglobin concentration is normal such as in hypoxic hypoxia. The other is called anemic hypoxia, where the hemoglobin concentration is decreased and but arterial $\mathrm{PO}_{2}$ is normal resulting in a decreased venous $\mathrm{PO}_{2}$ (Eckardt and Kurtz, 2005). There appears no difference in the effectiveness to produce EPO between these two situations. A mixture of these conditions might be a situation causing a decreased blood flow to the kidney at normal $\mathrm{PO}_{2}$ and hemoglobin concentration, which should also result in decreased capillary and venous $\mathrm{PO}_{2}$. The exact mechanisms controlling EPO production by the fibroblasts is not fully understood but appears to involve hypoxia-dependent recruitment of fibroblasts located in juxta-medullary and cortical regions (Eckardt et al., 1993).

EPO released into blood has many functions other than stimulating erythropoiesis (for review see Sasaki, 2003). In the bone marrow EPO binds to EPO receptors on progenitor cells in erythroblastic islands (Chasis and Mohandas, 2008), where it stimulates proliferation and prevents apoptotic destruction of newly formed cells (Lee and Percy, 2010). This increases the amount of red blood cells released from the bone marrow per time resulting in increased tEV when the rate of release exceeds red blood cell destruction (see above, sports anemia).

\section{Effects of exercise and training on erythropoiesis}

The increased $\mathrm{tHb}$ and $\mathrm{tEV}$ in trained athletes indicates that exercise stimulates erythropoiesis. An additional marker is the elevation of reticulocytes counts which can be observed within 1-2 days (Schmidt et al., 1988) after endurance (Convertino, 1991) and strength training units (Schobersberger et al., 1990). Despite apparent effects of single training units on red blood cell production several studies show that reticulocyte counts in athletes are not much different from sedentary controls (Lombardi et al., 2013) and values appear quite stable over years (Banfi et al., 2011; Diaz et al., 2011). There is, however, significant variation of reticulocyte counts in athletes during the year showing in general higher reticulocyte counts at the beginning of a season but lower values after intensive training sessions, competitions, and at the end of a season (Banfi et al., 2011). Nevertheless, markers of premature forms of reticulocytes are increased in athletes, which is indicative of stimulated bone marrow (Diaz et al., 2011; Jelkmann and Lundby, 2011).

Whereas the control of erythropoiesis in hypoxic and anemic hypoxia is well-understood, the signals stimulating erythropoiesis upon training in normoxia are unclear. Exposure to hypoxia causes a fast increase in EPO (Eckardt et al., 1989), but no or only minor changes in EPO have been observed after exercise of different modalities in untrained and trained individuals (Schmidt et al., 1991; Bodary et al., 1999), whereas the time course of 
change in reticulocyte count is similar to effects of high altitude (Schmidt et al., 1988; Mairbäurl et al., 1990). The higher reticulocyte counts, a decreased mean red blood cell buoyant density and mean corpuscular hemoglobin concentration, and increased levels of other markers of a decreased mean red blood cell age (higher 2,3-DPG and $\mathrm{P}_{50}$, higher red blood cell enzyme activities and creatine) have been found in peripheral blood from trained individuals (Mairbäurl et al., 1983; Schmidt et al., 1988), which are all indicators of an increased red blood cell turnover (Schmidt et al., 1988; Smith, 1995) and thus stimulated erythropoiesis. These newly formed red blood cells ease the passage of blood through capillaries because of a higher membrane fluidity and deformability of (Kamada et al., 1993).

Arguments for hypoxia as the relevant trigger for exercise induced erythropoiesis are sparse, and are at best indirect. Even during heavy exercise there is only a small decrease in arterial $\mathrm{PO}_{2}$ (see chapter 2, arterial $\mathrm{O}_{2}$ loading) that by itself will barely be sufficient to cause relevant renal EPO production. There is, however, a considerable decrease in renal blood flow with increasing exercise intensity that decreases renal $\mathrm{O}_{2}$ supply (for an excellent review on splanchnic blood flow regulation in exercise see Laughlin et al., 2012). The $\mathrm{O}_{2}$ supply to renal tubules might be further decreased, because renal cortical arteries and veins run parallel allowing exchange diffusion of $\mathrm{O}_{2}$ that may cause arterial deoxygenation. $\mathrm{PO}_{2}$ in cortical veins is low because of the high oxygen consumption required for $\mathrm{Na}^{+}$and water reabsorption of renal cortical epithelial cells (Eckardt and Kurtz, 2005). It can therefore be speculated that the decreased flow during exercise further decreases renal cortical $\mathrm{PO}_{2}$ to a level causing significant hypoxia of the peritubular, EPO producing fibroblasts during exercise, and that this effect is aggravated as exercise intensity increases. Interestingly, training attenuates the decrease in renal blood flow, which seems more pronounced following endurance than high-intensity interval sprint training in rats (Musch et al., 1991; Padilla et al., 2011), which might explain the weak erythropoietic response in highly trained athletes.

A variety of humoral factors known to affect erythropoiesis also change during exercise. Androgens are long known for their stimulatory effect on erythropoiesis by stimulation of EPO release, increasing bone marrow activity, and iron incorporation into the red cells, which is best indicated by polycythemia as a consequence of androgen therapy (Shahidi, 1973; Shahani et al., 2009). Endurance exercise and resistance training cause a transient increase in testosterone levels in men and women (Hackney, 2001; Enea et al., 2009). Post-exercise values vary with exercise intensity in both genders. Interestingly, post-exercise testosterone levels also directly change with mood (win vs. loss), which seems more pronounced in men than women (for review see Shahani et al., 2009).

Stress hormones such as catecholamines and cortisol stimulate the release of reticulocytes from the bone marrow and possibly also enhance erythropoiesis (Dar et al., 2011; Hu and Lin, 2012). Erythropoiesis is also stimulated by growth hormone and insulinlike growth factors (Kurtz et al., 1988; Christ et al., 1997) which also increase during exercise (Hakkinen and Pakarinen, 1995; Schwarz et al., 1996).

\section{HEMORHEOLOGY}

Hematocrit not only affects the amount of $\mathrm{O}_{2}$ that can be carried per volume of blood but also affects the rheological properties of blood. Due to its composition of plasma and blood cells it behaves as a non-Newtonian fluid, whose inner viscosity is affected by the shear forces and is determined by the concentration of plasma proteins (plasma viscosity), the physico-chemical properties of the red blood cell plasma membrane (deformability) and cellular hemoglobin concentration (cytosolic viscosity), the flow velocity (aggregation), and temperature (for review see El-Sayed et al., 2005). A high blood viscosity causes a high resistance to flow, increases the power output of the heart at a given cardiac output, and might impair local blood flow.

Because of the axial migration of blood cells when blood is moved with a high velocity it has been argued that plasma viscosity is the major determinant of whole blood viscosity (Rand et al., 1970). It is determined by the concentration of plasma proteins. The effect of altered hematocrit on blood viscosity is less clear. In vitro, a linear relation between blood viscosity and hematocrit values between $20 \%$ and $60 \%$ has been reported, when the shear stress is low (Chien et al., 1966), which is likely due to aggregation of red blood cells (Chien et al., 1967). Aggregation varies inversely with the flow velocity (Loewe and Barbenel, 1988) and is favored by fibrogen and immune-globulins binding to the red blood cells, whereas a role for albumin is less clear (Reinhart and Nagy, 1995). The high deformability of the red blood cells facilitates blood flow even at high hematocrit, particularly in the microcirculation. In fact, improved deformability contributes to the decrease in viscosity at high shear rates (El-Sayed et al., 2005). In contrast, increased osmolality decreases deformability by an increase of internal viscosity and altered surface-to-volume ratio although effects are small in the physiological range of changes in red blood cell hemoglobin concentration (Mohandas et al., 1980). Deformability of red blood cells has a temperature optimum in the physiological range and decreases significantly at temperatures below $35^{\circ} \mathrm{C}$ and above $45^{\circ} \mathrm{C}$ (Hanss and Koutsouris, 1984), which seems to be mainly determined by the lipid composition of the plasma membrane (Heath et al., 1982), whereas variations of the intracellular hemoglobin concentration within the physiological range do not affect deformability (Mohandas and Chasis, 1993).

Exercise and training affect all of the above mentioned determinants of whole blood viscosity. There is a well-documented increase in whole blood viscosity during exercise which reverses rapidly (for review see El-Sayed et al., 2005). It is mostly due to hemo-concentration and dehydration (Platt et al., 1981; Galea and Davidson, 1985; Vandewalle et al., 1988; Geor et al., 1994; Yalcin et al., 2000). Results on exercise induced changes in the deformability of red blood cells are divergent and indicate decreased (most reports; e.g., Platt et al., 1981; Geor et al., 1994; van der Brug et al., 1995; Bouix et al., 1998; Smith et al., 2013), unchanged (Neuhaus et al., 1992), and increased deformability (Gurcan et al., 1998) (for review see El-Sayed et al., 2005). Exercise in hypoxia aggravated the adverse effect on deformability, which was associated with decreased actin and spectrin content and down-regulation of other proteins, and enhanced the response of red blood cells to oxidative stress (Mao et al., 
2011). However, the exercise-induced decrease in deformability appears to be independent of oxidants produced by shear stress, because it was not prevented by strong antioxidant prophylaxis (Kayatekin et al., 2005). Studies may be hampered by the fact that PV and osmolality changes may revert rapidly depending on exercise duration and intensity indicating the proper choice of time-points for sampling when blood is collected after rather than during the exercise. Ernst and colleagues nicely report during and after exercise kinetics of blood viscosity and show that deformability of erythrocytes is increased during and normalized within a few hours after exercise (Ernst et al., 1991). The increase in blood lactate during exercise seems not to affect deformability (Simmonds et al., 2013), neither does lactate affect aggregation (Connes et al., 2007). However, there are indications that high lactate impairs deformability in untrained but improves in trained individuals (Connes et al., 2004). Training might decrease blood viscosity by improving the deformability of red blood cells. The membrane fluidity of red blood cells was increased in sprinters and long distance runners (Kamada et al., 1993), which is consistent with the finding that the exercise-induced decreased in deformability was found to be attenuated by training (Ernst, 1987; Yalcin et al., 2000). This might be explained by the higher deformability of newly formed red blood cells (Mairbäurl et al., 1983; Linderkamp et al., 1993). Erythropoietin, which was found slightly elevated (see above) seems to be favorable (Pichon et al., 2013; Zhao et al., 2013), probably by decreasing the mean red blood cell age and young red blood cells having an improved membrane flexibility (Mohandas and Chasis, 1993). In contrast, insulin-like growth factors and growth hormone seem to increase viscosity (Monnier et al., 2000; Connes et al., 2007). In summary, most studies show improved rheological properties of blood in trained individuals (see meta-analysis by Romain et al., 2011).

Together these results indicate that the increase in whole blood viscosity during exercise is caused by the combined effects of increased plasma viscosity and decreased deformability of the red blood cells, and potentially impairs microcirculation and thus $\mathrm{O}_{2}$ delivery to working muscle. Moderation of this effect might be brought about by NO released from endothelium and red blood cells with increased shear stress, because nitrosylation of cytoskeletal proteins in the red blood cell membrane seems to improve deformability (Grau et al., 2013). In contrast, training seems to increase deformability and to decrease whole blood viscosity in support of tissue oxygenation.

\section{RED BLOOD CELL MEDIATED VASODILATION}

Precise control of regional blood flow is required to match substrate demand and removal of metabolites, which is of particular importance when the metabolic activity is high such as in exercising skeletal muscle. Nitric oxide (NO) is an important signaling molecule that causes local vasodilation. It is typically formed in vascular endothelial cells upon a variety of stimuli, the most important during exercise likely being shear stress (Pohl et al., 1986; Shen et al., 1995). Hemoglobin has been shown to tightly bind $\mathrm{NO}$ to form nitrosylhemoglobin (Hb-cys-NO; $\mathrm{SNO}-\mathrm{Hb}$ ) in an $\mathrm{O}_{2}$ saturation dependent manner with higher affinity for deoxyhemoglobin, a reaction that also causes formation of Met-Hb (Gow and Stamler, 1998; Grubina et al., 2007).
Binding has been interpreted as a sink for NO produced by endothelium to prevent exaggerated and wide-spread vasodilation. However, it has also been hypothesized that $\mathrm{Hb}$ not only binds but also releases and/or produces NO from SNO-Hb to cause local vasodilation (Robinson and Lancaster, 2005).

It has been shown experimentally that NO released from red blood cells causes vasodilation when the shear stress is increased and when the tissue is made hypoxic (Ulker et al., 2013). Red blood cells produce bioactive NO equivalents in an $\mathrm{O}_{2}$ saturation, $\mathrm{pH}$, and redox-state dependent manner, which appears to be an allosteric, autocatalytic reaction with characteristics of a nitrite reductase reaction (for review see Gladwin and Kim-Shapiro, 2008). When nitrite is added to fully deoxygenated $\mathrm{Hb}$, NO is released and Met-Hb is formed (Gladwin and Kim-Shapiro, 2008). Bioactivity is indicated by the notion that upon nitrate infusion, NO binding to hemoglobin and vasodilation are tightly coupled and are favored by hypoxia (Crawford et al., 2006). Kleinbongard et al. (2006) presented immunehistochemical and functional evidence of the presence of an endothelial NO-synthase type of enzyme in human and mouse red blood cells indicating the potential to produce NO from Larginine. It is unclear, however, whether this reaction is active in controlling microcirculation in working skeletal muscle (which generates a low oxygen environment because of its requirement for oxygen).

ATP in plasma is another stimulus for endothelial NO production (Sprague et al., 1996). ATP is released from many cells where it modifies a variety of functions (Praetorius and Leipziger, 2009). Local vasodilation has been shown to depended on the presence of red blood cells (Dietrich et al., 2000). Thus, it has been hypothesized that red blood cells release ATP and cause an NO-dependent increase in blood flow (Gonzalez-Alonso et al., 2002). ATP release is not only an in vitro phenomenon but has also been demonstrated vivo, where elevated ATP has been found in the venous effluent from exercising forearm muscle (Forrester, 1972; Ellsworth et al., 1995). This effect was even enhanced when exercise was performed in hypoxia (Gonzalez-Alonso et al., 2002).

The major stimulus for ATP release from red blood cells seems to be mechanical deformation (Sprague et al., 1996; Ellsworth et al., 2009), where ATP release seems to depend on the shear rate (Mairbäurl et al., 2013). Also in vitro hypoxia stimulates the release of ATP from red blood cells (Bergfeld and Forrester, 1992). Futhermore, hypoxia greatly enhances ATP release induced by shear stress indicating that effects are additive (Mairbäurl et al., 2013). Other stimulators of ATP release from red blood cells are beta adrenergic stimulators and prostacyclin (Olearczyk et al., 2001), and an increase in temperature (Kalsi and GonzalezAlonso, 2012). The exact release mechanism is unclear. An involvement of CFTR has been discussed (Sprague et al., 1998) but it is unclear whether CFTR is actually present in human red blood cells. A variety of other mechanisms for ATP release have been described (for review see Praetorius and Leipziger, 2009), some of which seem to involve pannexin1- (Qiu and Dahl, 2009; Qiu et al., 2011). Intravascular hemolysis seems not to contribute significantly to ATP release from erythrocytes exposed to shear-stress (Mairbäurl et al., 2013). 


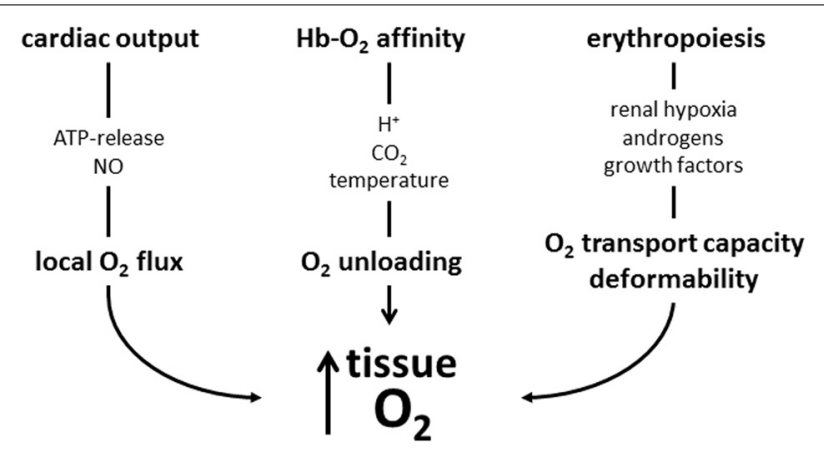

FIGURE 3 | Schematic presentation of mechanisms increasing muscle oxygen supply acutely during exercise and by training discussed in this review. During exercise local blood flow is increased by mediators causing local vasodilation, which is supported by red blood cell-mediated $\mathrm{NO}$ production. Acidosis, $\mathrm{CO}_{2}$ and hyperthermia decrease $\mathrm{Hb}_{-} \mathrm{O}_{2}$-affinity and enhance $\mathrm{O}_{2}$ release from its bond to hemoglobin. These improvements may in part be blunted by increased blood viscosity (not shown in scheme). Training stimulates erythropoiesis to increase the $\mathrm{O}_{2}$-transport capacity. The newly formed cells also have an improved deformability which facilitates muscle blood flow. Training also increases red blood cell 2,3-DPG (not shown), which further enhances $\mathrm{O}_{2}$ release from $\mathrm{Hb}$.

Taken together these results indicate that red blood cells support local vasodilation in tissues with a high $\mathrm{O}_{2}$ demand by directly mediating NO release and enzymatic production and by release of ATP, which causes NO release from endothelial cells by mechanisms, which are greatly enhanced in exercise when shear stress is increased by increased blood flow, $\mathrm{O}_{2}$ is low due to increased consumption, and the increase in temperature.

\section{CONCLUSION}

There are many mechanisms that contribute to an increased tissue oxygen supply during exercise. Figure 3 summarizes those, where red blood cell are involved. They involve adjustments during exercise and to training. During exercise the increased $\mathrm{O}_{2}$ demand of skeletal muscle is mainly matched by increasing muscle blood flow by increasing cardiac output, by modulating blood flow distribution among active and inactive organs, and by optimizing microcirculation (Laughlin et al., 2012). Red blood cells support local blood flow by providing the vasodilator NO by direct conversion from nitrate and by release of ATP causing endothelial $\mathrm{NO}$ release. At any given capillary blood flow the amount of $\mathrm{O}_{2}$ unloaded from $\mathrm{Hb}$ to the cells of working muscle can be increased greatly by decreasing $\mathrm{Hb}-\mathrm{O}_{2}$ affinity. This happens as the cells enter the capillaries supplying the muscle cells, where they are exposed to increased temperature, $\mathrm{H}^{+}$and $\mathrm{CO}_{2}$. Training further enhances $\mathrm{O}_{2}$ flux to the working muscle at all levels of regulation: It increases maximal cardiac output, improves blood flow to the muscles by stimulating vascularization, and improves the rheological properties of red blood cells. Training increases total hemoglobin mass by stimulating erythropoiesis, which increases the amount of $\mathrm{O}_{2}$ that can be carried by blood. It also increases red blood cell 2,3-DPG, which increases the sensitivity of Hb$\mathrm{O}_{2}$ affinity to acidification dependent $\mathrm{O}_{2}$-release. The system appears to be optimized for exercise at low altitude, because in an hypoxic environment the decreased arterial $\mathrm{PO}_{2}$, which is the major determinant for $\mathrm{O}_{2}$ diffusion, cannot be compensated adequately by the above mentioned $\mathrm{O}_{2}$ transport mechanisms resulting in a decrease in performance with increasing degree of hypoxia (Cerretelli and DiPrampero, 1985).

\section{REFERENCES}

Arnold, H. R., Carrier, E. B., Smith, H. P., and Whipple, G. H. (1921). Blood volume studies. Am. J. Physiol. 56, 313-327.

Banfi, G., Lundby, C., Robach, P., and Lippi, G. (2011). Seasonal variations of haematological parameters in athletes. Eur. J. Appl. Physiol. 111, 9-16. doi: 10.1007/s00421-010-1641-1

Bauer, C. (1969). Antagonistic influence of $\mathrm{CO}_{2}$ and 2, 3 Diphosphoglycerate on the Bohr Effect of human Haemoglobin. Life Sci. 8, 1041-1046. doi: 10.1016/00243205(69)90455-X

Benesch, R., and Benesch, R. E. (1967). The effect of organic phosphates from human erythrocytes on the allosteric properties of hemoglobin. Biochem. Biophys. Res. Commun. 26, 162-167. doi: 10.1016/0006-291X(67)90228-8

Bergfeld, G. R., and Forrester, T. (1992). Release of ATP from human erythrocytes in response to a brief period of hypoxia and hypercapnia. Cardiovasc. Res. 26, 40-47. doi: 10.1093/cvr/26.1.40

Berglund, B., and Hemmingson, P. (1987). Effect of reinfusion of autologous blood on exercise performance in cross-country skiers. Int. J. Sports Med. 8, 231-233. doi: 10.1055/s-2008-1025661

Berlin, G., Challoner, K. E., and Woodson, R. D. (2002). Low $\mathrm{O}_{2}$ affinity erythrocytes improve performance of ischemic myocardium. J. Appl. Physiol 92, 1267-1276. doi: 10.1152/japplphysiol.00194.2001

Bert, P. (1882). Sur la richesse en hemoglobine du sang des animaux vivant sur les haut lieux. C. R. Acad. Sci. (Paris) 94, 805-807.

Bodary, P. F., Pate, R. R., Wu, Q. O. F., and McMillan, G. S. (1999). Effects of acute exercise on plasma erythropoietin levels in trained runners. Med. Sci. Sports Exerc. 31, 543-546. doi: 10.1097/00005768-199904000-00008

Böning, D., Maassen, N., and Pries, A. (2011). The hematocrit paradox-how does blood doping really work. Int. J. Sports Med. 32, 242-246. doi: 10.1055/s-00301255063

Böning, D., Mrugalla, M., Maassen, N., Busse, M., and Wagner, T. O. (1988). Exercise versus immersion: antagonistic effects on water and electrolyte metabolism during swimming. Eur. J. Appl. Physiol. Occup. Physiol. 57, 248-253. doi: 10.1007/BF00640671

Böning, D., Schweigart, U., Tibes, U., and Hemmer, B. (1975). Influences of exercise and endurance training on the oxygen dissociation curve of blood under in vivo and in vitro conditions. Eur. J. Appl. Physiol. 34, 1-10. doi: 10.1007/BF00999910

Bouix, D., Peyreigne, C., Raynaud, E., Monnier, J. F., Micallef, J. P., and Brun, J. F. (1998). Relationships among body composition, hemorheology and exercise performance in rugbymen. Clin. Hemorheol. Microcirc. 19, 245-254.

Braumann, K. M., Böning, D., and Trost, F. (1982). Bohr effect and slope of the oxygen dissociation curve after physical training. J. Appl. Physiol. 52, $1524-1529$.

Broun, G. O. (1922). Blood destruction during exercise: i. blood changes occurring in the course of a single day of exercise. J. Exp. Med. 36, 481-500. doi: 10.1084/jem.36.5.481

Calbet, J. A., Lundby, C., Koskolou, M., and Boushel, R. (2006). Importance of hemoglobin concentration to exercise: acute manipulations. Respir. Physiol. Neurobiol. 151, 132-140. doi: 10.1016/j.resp.2006.01.014

Calbet, J. A., Robach, P., Lundby, C., and Boushel, R. (2008). Is pulmonary gas exchange during exercise in hypoxia impaired with the increase of cardiac output. Appl. Physiol. Nutr. Metab. 33, 593-600. doi: 10.1139/H08-010

Carroll, S. B. (2007). The Making of the Fittest. New York, NY: Norton.

Chasis, J. A., and Mohandas, N. (2008). Erythroblastic islands: niches for erythropoiesis. Blood 112, 470-478. doi: 10.1182/blood-2008-03-077883

Cerretelli, P., and DiPrampero, P. E. (1985). "Aerobic and anaerobic metabolism during exercise at altitude," in High Altitude Deterioration, eds J. Rivolier, P. Cerretelli, J. Foray and P. Segantini (Basel: Karger), 1-19.

Chien, S., Usami, S., Dellenback, R. J., Gregersen, M. I., Nanninga, L. B., and Guest, M. M. (1967). Blood viscosity: influence of erythrocyte aggregation. Science 157, 829-831. doi: 10.1126/science.157.3790.829

Chien, S., Usami, S., Taylor, H. M., Lundberg, J. L., and Gregersen, M. I. (1966). Effects of hematocrit and plasma proteins on human blood rheology at low shear rates. J. Appl. Physiol. 21, 81-87. 
Christ, E. R., Cummings, M. H., Westwood, N. B., Sawyer, B. M., Pearson, T. C., Sonksen, P. H., et al. (1997). The importance of growth hormone in the regulation of erythropoiesis, red cell mass, and plasma volume in adults with growth hormone deficiency. J. Clin. Endocrinol. Metab. 82, 2985-2990. doi: 10.1210/jc.82.9.2985

Connes, P., Bouix, D., Py, G., Prefaut, C., Mercier, J., Brun, J. F., et al. (2004). Opposite effects of in vitro lactate on erythrocyte deformability in athletes and untrained subjects. Clin. Hemorheol. Microcirc. 31, 311-318.

Connes, P., Caillaud, C., Py, G., Mercier, J., Hue, O., and Brun, J. F. (2007). Maximal exercise and lactate do not change red blood cell aggregation in well trained athletes. Clin. Hemorheol. Microcirc. 36, 319-326.

Convertino, V. A. (1987). Fluid shifts and hydration state: effects of long-term exercise. Can. J. Sport Sci. 12, 136S-139S.

Convertino, V. A. (1991). Blood volume: its adaptation to endurance training. Med. Sci. Sports Exerc. 23, 1338-1348. doi: 10.1249/00005768-199112000-00004

Costill, D. L., Branam, G., Fink, W., and Nelson, R. (1976). Exercise induced sodium conservation: changes in plasma renin and aldosterone. Med. Sci. Sports 8, 209-213. doi: 10.1249/00005768-197600840-00001

Costill, D. L., Branam, L., Eddy, D., and Fink, W. (1974). Alterations in red cell volume following exercise and dehydration. J. Appl. Physiol. 37, 912-916.

Crawford, J. H., Isbell, T. S., Huang, Z., Shiva, S., Chacko, B. K., Schechter, A. N., et al. (2006). Hypoxia, red blood cells, and nitrite regulate NO-dependent hypoxic vasodilation. Blood 107, 566-574. doi: 10.1182/blood-2005-07-2668

Dar, A., Schajnovitz, A., Lapid, K., Kalinkovich, A., Itkin, T., Ludin, A., et al. (2011). Rapid mobilization of hematopoietic progenitors by AMD3100 and catecholamines is mediated by CXCR4-dependent SDF-1 release from bone marrow stromal cells. Leukemia 25, 1286-1296. doi: 10.1038/leu.2011.62

Davies, J. E., and Brewer, N. (1935). Effect of physical training on blood volume, hemoglobin, alkali reserve and osmotic resistance of erythrocytes. Am. J. Physiol. 113, 586-591. doi: 10.3181/00379727-32-8059P

Dempsey, J. A., and Wagner, P. D. (1999). Exercise-induced arterial hypoxemia. J. Appl. Physiol. 87, 1997-2006. doi: 10.1249/00005768-199305001-01038

Deuticke, B. (1982). Monocarboxylate transport in erythrocytes. J. Membr. Biol. 70, 89-103. doi: 10.1007/BF01870219

Diaz, V., Lombardi, G., Ricci, C., Jacobs, R. A., Montalvo, Z., Lundby, C., et al. (2011). Reticulocyte and haemoglobin profiles in elite triathletes over four consecutive seasons. Int. J. Lab. Hematol. 33, 638-644. doi: 10.1111/j.1751553X.2011.01348.x

Dietrich, H. H., Ellsworth, M. L., Sprague, R. S., and Dacey, R. G. Jr. (2000). Red blood cell regulation of microvascular tone through adenosine triphosphate. Am. J. Physiol. Heart Circ. Physiol. 278, H1294-H1298.

Dill, D. B., and Forbes, W. H. (1941). Respiratory and metabolic effects of hypothermia. Am. J. Physiol. 132, 685-697.

Dressendorfer, R. H., Wade, C. E., and Frederick, E. C. (1992). Effect of shoe cushioning on the development of reticulocytosis in distance runners. Am. J. Sports Med. 20, 212-216. doi: 10.1177/036354659202000221

Eaton, J. W., Skelton, T. D., and Berger, E. (1974). Survival at extreme altitude: protective effect of increased hemoglobin-oxygen affinity. Science 183, 743-744. doi: 10.1126/science.183.4126.743

Eckardt, K. U., Boutellier, U., Kurtz, A., Schopen, M., Koller, E. A., and Bauer, C. (1989). Rate of erythropoietin formation in humans in response to acute hypobaric hypoxia. J. Appl. Physiol. 66, 1785-1788.

Eckardt, K. U., Koury, S. T., Tan, C. C., Schuster, S. J., Kaissling, B., Ratcliffe, P. J., et al. (1993). Distribution of erythropoietin producing cells in rat kidneys during hypoxic hypoxia. Kidney Int. 43, 815-823. doi: 10.1038/ki.1993.115

Eckardt, K. U., and Kurtz, A. (2005). Regulation of erythropoietin production. Eur. J. Clin. Invest. 35, 13-19. doi: 10.1111/j.1365-2362.2005.01525.x

Ellsworth, M. L., Ellis, C. G., Goldman, D., Stephenson, A. H., Dietrich, H. H., and Sprague, R. S. (2009). Erythrocytes: oxygen sensors and modulators of vascular tone. Physiology 24, 107-116. doi: 10.1152/physiol.00038.2008

Ellsworth, M. L., Forrester, T., Ellis, C. G., and Dietrich, H. H. (1995). The erythrocyte as a regulator of vascular tone. Am. J. Physiol. 269, H2155-H2161.

El-Sayed, M. S., Ali, N., and El-Sayed, A. Z. (2005). Haemorheology in exercise and training. Sports Med. 35, 649-670. doi: 10.2165/00007256-20053508000001

Enea, C., Boisseau, N., Ottavy, M., Mulliez, J., Millet, C., Ingrand, I., et al. (2009). Effects of menstrual cycle, oral contraception, and training on exercise-induced changes in circulating DHEA-sulphate and testosterone in young women. Eur. J. Appl. Physiol 106, 365-373. doi: 10.1007/s00421-009-1017-6
Ernst, E. (1987). Influence of regular physical activity on blood rheology. Eur. Heart J. 8(Suppl. G), 59-62. doi: 10.1093/eurheartj/8.suppl_G.59

Ernst, E., Daburger, L., and Saradeth, T. (1991). The kinetics of blood rheology during and after prolonged standardized exercise. Clin. Hemorheol. Microcirc. 11, 429-439.

Forrester, T. (1972). An estimate of adenosine triphosphate release into the venous effluent from exercising human forearm muscle. J. Physiol. 224, 611-628.

Friedmann, B., Frese, F., Menold, E., Kauper, F., Jost, J., and Bartsch, P. (2005). Individual variation in the erythropoietic response to altitude training in elite junior swimmers. Br. J. Sports Med. 39, 148-153. doi: 10.1136/bjsm.2003.011387

Friedmann, B., Jost, J., Rating, T., Weller, E., Werle, E., Eckardt, K.-U., et al. (1999). Effects of iron supplementation on total body hemoglobin during endurance training at moderate altitude. Int. J. Sports Med. 20, 78-85.

Galea, G., and Davidson, R. J. (1985). Hemorrheology of marathon running. Int. J. Sports Med. 6, 136-138. doi: 10.1055/s-2008-1025826

Geor, R. J., Weiss, D. J., and Smith, C. M. (1994). Hemorheologic alterations induced by incremental treadmill exercise in thoroughbreds. Am. J. Vet. Res. 55, 854-861.

Gladwin, M. T., and Kim-Shapiro, D. B. (2008). The functional nitrite reductase activity of the heme-globins. Blood 112, 2636-2647. doi: 10.1182/blood-200801-115261

Godin, G., and Shephard, R. J. (1972). On the course of carbon monoxide uptake and release. Respiration 29, 317-329. doi: 10.1159/000192905

Gonzalez-Alonso, J., Olsen, D. B., and Saltin, B. (2002). Erythrocyte and the regulation of human skeletal muscle blood flow and oxygen delivery: role of circulating ATP. Circ. Res. 91, 1046-1055. doi: 10.1161/01.RES.0000044939.73286.E2

Görlach, A. (2009). Regulation of HIF-lalpha at the transcriptional level. Curr. Pharm. Des 15, 3844-3852. doi: 10.2174/138161209789649420

Gow, A. J., and Stamler, J. S. (1998). Reactions between nitric oxide and haemoglobin under physiological conditions. Nature 391, 169-173. doi: $10.1038 / 34402$

Grau, M., Pauly, S., Ali, J., Walpurgis, K., Thevis, M., Bloch, W., et al. (2013). RBC-NOS-dependent S-nitrosylation of cytoskeletal proteins improves RBC deformability. PLoS ONE 8:e56759. doi: 10.1371/journal.pone.0056759

Green, H. J., Sutton, J. R., Coates, G., Ali, M., and Jones, S. (1991). Response of red cell and plasma volume to prolonged training in humans. J. Appl. Physiol. 70, 1810-1815.

Grehant, M., and Quinquard, E. (1882). Mesures du volume du sang contenu dans l'organisme d'un mammifére vivant. C. R. Acad. Sci. 94:1450.

Gruber, M., Hu, C. J., Johnson, R. S., Brown, E. J., Keith, B., and Simon, M. C. (2007). Acute postnatal ablation of Hif-2alpha results in anemia. Proc. Natl. Acad. Sci. U.S.A. 104, 2301-2306. doi: 10.1073/pnas.0608382104

Grubina, R., Huang, Z., Shiva, S., Joshi, M. S., Azarov, I., Basu, S., et al. (2007). Concerted nitric oxide formation and release from the simultaneous reactions of nitrite with deoxy- and oxyhemoglobin. J. Biol. Chem. 282, 12916-12927. doi: 10.1074/jbc.M700546200

Gurcan, N., Erbas, D., Ergen, E., Bilgehan, A., Dundar, S., Aricioglu, A., et al. (1998). Changes in blood haemorheological parameters after submaximal exercise in trained and untrained subjects. Physiol. Res. 47, 23-27.

Haase, V. H. (2010). Hypoxic regulation of erythropoiesis and iron metabolism. Am. J. Physiol. Ren. Physiol. 299, F1-F13. doi: 10.1152/ajprenal.00174.2010

Hackney, A. C. (2001). Endurance exercise training and reproductive endocrine dysfunction in men: alterations in the hypothalamic-pituitary-testicular axis. Curr. Pharm. Des 7, 261-273. doi: 10.2174/1381612013398103

Hagberg, J. M., Goldberg, A. P., Lakatta, L., F.C.O'Connor, Becker, L. C., Lakatta, E. G., et al. (1998). Expanded blood volumes contribute to the increased cardiovascular performance of endurance-trained older men. J. Appl. Physiol. 85, 484-489.

Haidas, S., Labie, D., and Kaplan, J. C. (1971). 2, 3-Diphosphoglycerate content and oxygen affinity as a function of red cell age in normal individuals. Blood 38/4, 463-467.

Hakkinen, K., and Pakarinen, A. (1995). Acute hormonal responses to heavy resistance exercise in men and women at different ages. Int. J. Sports Med. 16, 507-513. doi: 10.1055/s-2007-973045

Hanss, M., and Koutsouris, D. (1984). Thermal transitions of red blood cell deformability. Correlation with membrane rheological properties. BBA 769, 461-470. doi: 10.1016/0005-2736(84)90331-6

Harrison, M. H. (1985). Effects on thermal stress and exercise on blood volume in humans. Physiol. Rev. 65, 149-209. 
Heath, B. P., Mohandas, N., Wyatt, J. L., and Shohet, S. B. (1982). Deformability of isolated red blood cell membranes. BBA 691, 211-219. doi: 10.1016/00052736(82)90409-6

Hebbel, R. P., Eaton, J. W., Kronenberg, R. S., Zanjani, E. D., Moore, L. G., and Berger, E. M. (1978). Human Llamas. Adaptation to altitude in subjects with high hemoglobin oxygen affinity. J. Clin. Invest. 62, 593-600. doi: 10.1172/JCI109165

Heinicke, K., Heinicke, I., Schmidt, W., and Wolfarth, B. (2005). A three-week traditional altitude training increases hemoglobin mass and red cell volume in elite biathlon athletes. Int. J. Sports Med. 26, 350-355. doi: 10.1055/s-2004-821052

Heinicke, K., Wolfarth, B., Winchenbach, P., Biermann, B., Schmid, A., Huber, G., et al. (2001). Blood volume and hemoglobin mass in elite athletes of different disciplines. Int. J. Sports Med. 22, 504-512. doi: 10.1055/s-2001-17613

Hopkins, S. R. (2006). Exercise induced arterial hypoxemia: the role of ventilationperfusion inequality and pulmonary diffusion limitation. Adv. Exp. Med. Biol. 588, 17-30. doi: 10.1007/978-0-387-34817-9_3

Hu, C. J., Wang, L. Y., Chodosh, L. A., Keith, B., and Simon, M. C. (2003). Differential roles of hypoxia-inducible factor lalpha (HIF-1alpha) and HIF2alpha in hypoxic gene regulation. Mol. Cell Biol. 23, 9361-9374. doi: 10.1128/MCB.23.24.9361-9374.2003

$\mathrm{Hu}$, M., and Lin, W. (2012). Effects of exercise training on red blood cell production: implications for anemia. Acta Haematol. 127, 156-164. doi: $10.1159 / 000335620$

Hunding, A., Jordal, R., and Paulev, P. E. (1981). Runner's anemia and iron deficiency. Acta Med. Scand. 209, 315-318. doi: 10.1111/j.0954-6820.1981.tb11598.x

Hurtado, A. (1964). "Some physiological and clinical aspectsof life at high altitudes," in Aging of the Lung, eds L. Cander and J. H. Moyer (New York, NY: Grune and Stratton), 257.

Jelkmann, W., and Lundby, C. (2011). Blood doping and its detection. Blood 118 2395-2404. doi: 10.1182/blood-2011-02-303271

Jordan, J., Kiernan, W., Merker, H. J., Wenzel, M., and Beneke, R. (1998). Red cell membrane skeletal changes in marathon runners. Int. J. Sports Med. 19, 16-19. doi: 10.1055/s-2007-971873

Kalsi, K. K., and Gonzalez-Alonso, J. (2012). Temperature-dependent release of ATP from human erythrocytes: mechanism for the control of local tissue perfusion. Exp. Physiol. 97, 419-432. doi: 10.1113/expphysiol.2011.064238

Kamada, T., Tokuda, S., Aozaki, S. I., and Otsuji, S. (1993). Higher levels of erythrocyte membrane fluidity in sprinters and long-distance runners. J. Appl. Physiol. 74, 354-358

Kayatekin, B. M., Uysal, N., Resmi, H., Bediz, C. S., Temiz-Artmann, A., Genc, S., et al. (2005). Does antioxidant supplementation alter the effects of acute exercise on erythrocyte aggregation, deformability and endothelium adhesion in untrained rats. Int. J. Vitam. Nutr. Res. 75, 243-250. doi: 10.1024/0300 9831.75.4.243

Kjellberg, S. R., Rudhe, U., and Sjostrand, T. (1949). Increase of the amount of hemoglobin and blood volume in connection with physical training. Acto Physiol. Scand. 19, 146-152. doi: 10.1111/j.1748-1716.1949.tb00146.x

Kleinbongard, P., Schulz, R., Rassaf, T., Lauer, T., Dejam, A., Jax, T., et al. (2006). Red blood cells express a functional endothelial nitric oxide synthase. Blood 107 2943-2951. doi: 10.1182/blood-2005-10-3992

Kurtz, A., Zapf, J., Eckardt, K. U., Clemons, G., Froesch, E. R., and Bauer, C. (1988). Insulin-like growth factor I stimulates erythropoiesis in hypophysectomized rats. Proc. Natl. Acad. Sci. U.S.A. 85, 7825-7829. doi: 10.1073/pnas.85.20.7825

Kurz, E. R. (1948). March hemoglobinuria. Brooklyn. Hosp. J. 6, 91-94.

Laughlin, M. H., Davis, M. J., Secher, N. H., van Lieshout, J. J., Arce-Esquivel, A. A., Simmons, G. H., et al. (2012). Peripheral circulation. Compr. Physiol. 2, 321-447. doi: 10.1002/cphy.c100048

Ledingham, I. M. (1977). Factors influencing oxygen availability. J. Clin. Pathol. Suppl (R. Coll. Pathol.) 11, 1-6. doi: 10.1136/jcp.s3-11.1.1

Lee, F. S., and Percy, M. J. (2010). The HIF pathway and erythrocytosis. Annu. Rev. Pathol. 6, 165-192. doi: 10.1146/annurev-pathol-011110-130321

Levine, B. D., and Stray-Gundersen, J. (1997). "Living high-training low": effect of moderate-altitude acclimatization with low-altitude training on performance. J. Appl. Physiol. 83, 102-112.

Linderkamp, O., Friederichs, E., and Meiselman, H. J. (1993). Mechanical and geometrical properties of density-separated neonatal and adult erythrocytes. Pediatr. Res. 34, 688-693. doi: 10.1203/00006450-199311000-00024

Loewe, G. D., and Barbenel, J. C. (1988). “Clinical blood rheology,” in Plasma and Blood Viscosity, ed G. D. Loewe (Boca Raton, FL: CRC Press), 1-44.
Lombardi, G., Colombini, A., Lanteri, P., and Banfi, G. (2013). Reticulocytes in sports medicine: an update. Adv. Clin. Chem. 59, 125-153. doi: 10.1016/B9780-12-405211-6.00005-X

Magnusson, B., Hallberg, L., Rossander, L., and Swolin, B. (1984). Iron metabolism and "sports anemia". II. A hematological comparison of elite runners and control subjects. Acta Med. Scand. 216, 157-164. doi: 10.1111/j.09546820.1984.tb03787.x

Mairbäurl, H. (1994). Red blood cell function in hypoxia at altitude and exercise. Int. J. Sports Med. 15/2, 51-63. doi: 10.1055/s-2007-1021020

Mairbäurl, H., and Humpeler, E. (1980). Diminution of the temperature effect on the oxygen affinity of hemoglobin after prolonged hypothermia. Pflügers Arch. Eur. J. Physiol. 383, 209-213. doi: 10.1007/BF00587520

Mairbäurl, H., and Weber, R. E. (2012). Oxygen transport by hemoglobin. Compr Physiol. 2, 1463-1489. doi: 10.1002/cphy.c080113

Mairbäurl, H., Humpeler, E., Schwaberger, G., and Pessenhofer, H. (1983). Training dependent changes of red cell density and erythrocytic oxygen transport. J. Appl. Physiol. 55/5, 1403-1407.

Mairbäurl, H., Ruppe, F. A., and Bartsch, P. (2013). Role of hemolysis in red cell ATP release in simulated exercise conditions in vitro. Med. Sci. Sports Exerc. 45 , 1941-1947. doi: 10.1249/MSS.0b013e318296193a

Mairbäurl, H., Schobersberger, W., Hasibeder, W., Schwaberger, G., Gaesser, G., and Tanaka, K. R. (1986). Regulation of red cell 2, 3-DPG and Hb-O2-affinity during acute exercise. Eur. J. Appl. Physiol. 55, 174-180. doi: 10.1007/BF00715001

Mairbäurl, H., Schobersberger, W., Oelz, O., Bärtsch, P., Eckardt, K. U., and Bauer, C. (1990). Unchanged in-vivo $\mathrm{P}_{50}$ at high altitude despite decreased red cell age and elevated 2, 3-DPG. J. Appl. Physiol. 68/3, 1186-1194.

Mao, T. Y., Fu, L. L., and Wang, J. S. (2011). Hypoxic exercise training causes erythrocyte senescence and rheological dysfunction by depressed Gardos channel activity. J. Appl. Physiol. 111, 382-391. doi: 10.1152/japplphysiol. 00096.2011

Marti, H. H. (2005). Angiogenesis-a self-adapting principle in hypoxia. EXS 163-180. doi: 10.1007/3-7643-7311-3_12

Martin, D. T., Watts, P. B., and Newbury, V. S. (1992). The effect of alpine mountaineering on acute erythrocyte hemolysis. Int. J. Sports. Med. 13, 31-35. doi: $10.1055 / \mathrm{s}-2007-1021230$

Martin, H., and Kilian, P. (1959). [March hemoglobinuria (Studies on the mechanism of hemolysis and review of the literature)]. Folia Haematol. 4, 92-117.

Maxwell, P. H., Osmond, M. K., Pugh, C. W., Heryet, A., Nicholls, L. G., Tan, C. C., et al. (1993). Identification of the renal erythropoietin-producing cells using transgenic mice. Kidney Int. 44, 1149-1162. doi: 10.1038/ki.1993.362

Milledge, J. S., Bryson, E. I., Catley, D. M., Hesp, R., Luff, N., Minty, B. D., et al. (1982). Sodium balance, fluid homeostasis and the renin-aldosterone system during the prolonged exercise of hill walking. Clin. Sci. 62, 595-604.

Miller, B. J., Pate, R. R., and Burgess, W. (1988). Foot impact force and intravascular hemolysis during distance running. Int. J. Sports Med. 9, 56-60. doi: 10.1055/s2007-1024979

Mirand, E. A., and Prentice, T. C. (1957). Presence of plasma erythropoietin in hypoxic rats with or without kidney (s) and/or spleen. Proc. Soc. Exp. Biol. Med. 96, 49-51. doi: 10.3181/00379727-96-23390

Mohandas, N., and Chasis, J. A. (1993). Red blood cell deformability, membrane material properties and shape - regulation by transmembrane, skeletal and cytosolic proteins and lipids. Semin. Hematol. 30, 171-192.

Mohandas, N., Clark, M. R., Jacobs, M. S., and Shohet, S. B. (1980). Analysis of factors regulating erythrocyte deformability. J. Clin. Invest. 66, 563-573. doi: 10.1172/JCI109888

Monnier, J. F., Benhaddad, A. A., Micallef, J. P., Mercier, J., and Brun, J. F. (2000). Relationships between blood viscosity and insulin-like growth factor I status in athletes. Clin. Hemorheol. Microcirc. 22, 277-286.

Musch, T. I., Terrell, J. A., and Hilty, M. R. (1991). Effects of high-intensity sprint training on skeletal muscle blood flow in rats. J. Appl. Physiol 71, 1387-1395.

Myhre, L. G., Dill, D. B., Hall, F. G., and Brown, D. K. (1970). Blood volume changes during three-week residence at high altitude. Clin. Chem. 16, 7-14.

Nakatsuji, T., Oda, S., Fujita, H., Matsumoto, N., and Miwa, S. (1978). [Socalled march hemoglobinuria caused by "kendo" exercise: a report of two cases (author's author's transl)]. Rinsho Ketsueki 19, 1241-1246.

Neuhaus, D., Behn, C., and Gaehtgens, P. (1992). Haemorheology and exercise: intrinsic flow properties of blood in marathon running. Int. J. Sports Med. 13, 506-511. doi: 10.1055/s-2007-1021307 
Okada, Y., Tyuma, I., and Sugimoto, T. (1977). Evaluation of Severinghaus' equation and its modification for 2, 3-DPG. Jap. J. Physiol. 27, 135-144. doi: 10.2170/jjphysiol.27.135

Olearczyk, J. J., Stephenson, A. H., Lonigro, A. J., and Sprague, R. S. (2001). Receptor-mediated activation of the heterotrimeric G-protein Gs results in ATP release from erythrocytes. Med. Sci. Monit. 7, 669-674.

Padilla, J., Simmons, G. H., Bender, S. B., Arce-Esquivel, A. A., Whyte, J. J., and Laughlin, M. H. (2011). Vascular effects of exercise: endothelial adaptations beyond active muscle beds. Physiology. (Bethesda.) 26, 132-145. doi: 10.1152/physiol.00052.2010

Parisotto, R., Gore, C. J., Emslie, K. R., Ashenden, M. J., Brugnara, C., Howe, C., et al. (2000). A novel method utilising markers of altered erythropoiesis for the detection of recombinant human erythropoietin abuse in athletes. Haematologica 85, 564-572.

Pichon, A., Lamarre, Y., Voituron, N., Marchant, D., Vilar, J., Richalet, J. P., et al. (2013). Red blood cell deformability is very slightly decreased in erythropoietin deficient mice. Clin. Hemorheol. Microcirc. doi: 10.3233/CH-121654. [Epub ahead of print]

Platt, O. S., Lux, S. E., and Nathan, D. G. (1981). Exercise-induced hemolysis in xerocytosis. Erythrocyte dehydration and shear sensitivity. J. Clin. Invest. 68, 631-638. doi: 10.1172/JCI110297

Pohl, U., Busse, R., Kuon, E., and Bassenge, E. (1986). Pulsatile perfusion stimulates the release of endothelial autacoids. J. Appl. Cardiol. 1, 215-235.

Praetorius, H. A., and Leipziger, J. (2009). ATP release from non-excitable cells. Purinergic. Signal. 5, 433-446. doi: 10.1007/s11302-009-9146-2

Qiu, F., and Dahl, G. (2009). A permeant regulating its permeation pore: inhibition of pannexin 1 channels by ATP. Am. J. Physiol. Cell Physiol. 296, C250-C255. doi: 10.1152/ajpcell.00433.2008

Qiu, F., Wang, J., Spray, D. C., Scemes, E., and Dahl, G. (2011). Two non-vesicular ATP release pathways in the mouse erythrocyte membrane. FEBS Lett. 585, 3430-3435. doi: 10.1016/j.febslet.2011.09.033

Rand, P. W., Barker, N., and Lacombe, E. (1970). Effects of plasma viscosity and aggregation on whole-blood viscosity. Am. J. Physiol. 218, 681-688.

Rapoport, S. M. (1986). The Reticulocyte. Boca Raton, FL: CRC Press, Inc., Boca Raton, FLorida.

Reinhart, W. H., and Nagy, C. (1995). Albumin affects erythrocyte aggregation and sedimentation. Eur. J. Clin. Invest. 25, 523-528. doi: 10.1111/j.13652362.1995.tb01739.x

Remes, K. (1979). Effect of long-term physical training on total red cell volume. Scand. J. Clin. Lab. Invest. 39, 311-319. doi: 10.3109/00365517909106114

Reynafarje, C., Lozano, R., and Valdivieso, J. (1959). The polycythemia of high altitudes: iron metabolism and related aspects. Blood 14, 433-455.

Richalet, J. P., and Gore, C. J. (2008). Live and/or sleep high:train low, using normobaric hypoxia. Scand. J. Med. Sci. Sports 18(Suppl. 1), 29-37. doi: 10.1111/j.1600-0838.2008.00830.x

Robach, P., and Lundby, C. (2012). Is live high-train low altitude training relevant for elite athletes with already high total hemoglobin mass. Scand. J. Med. Sci. Sports 22, 303-305. doi: 10.1111/j.1600-0838.2012.01457.x

Robinson, J. M., and Lancaster, J. R. (2005). Hemoglobin-mediated, hypoxiainduced vasodilation via nitri c oxide - Mechanism(S) and physiologic versus pathophysiologic re levance. Am.er. J. Respir. Cell Mol.ec. Biol. 32, 257-261. doi: 10.1165/rcmb.F292

Robinson, Y., Cristancho, E., and Böning, D. (2006). Intravascular hemolysis and mean red blood cell age in athletes. Med. Sci. Sports Exerc. 38, 480-483. doi: 10.1249/01.mss.0000188448.40218.4c

Romain, A. J., Brun, J. F., Varlet-Marie, E., and Raynaud de, M. E. (2011). Effects of exercise training on blood rheology: a meta-analysis. Clin. Hemorheol. Microcirc. 49, 199-205. doi: 10.3233/CH-2011-1469

Roughton, F. J., and Severinghaus, J. W. (1973). Accurate determination of $\mathrm{O}_{2}$ dissociation curve of human blood above 98.7 percent saturation with data on $\mathrm{O}_{2}$ solubility in unmodified human blood from 0 degrees to 37 degrees C. J. Appl. Physiol. 35, 861-869.

Sallam, A. M., and Hwang, N. H. (1984). Human red blood cell hemolysis in a turbulent shear flow: contribution of Reynolds shear stresses. Biorheology 21, 783-797.

Sanchez, C., Merino, C., and Figallo, M. (1970). Simultaneous measurement of plasma volume and cell mass in polycythemia of high altitude. J. Appl. Physiol. $28,775-778$.
Sasaki, R. (2003). Pleiotropic functions of erythropoietin. Intern. Med. 42, 142-149. doi: 10.2169/internalmedicine.42.142

Sawka, M. N., Convertino, V. A., Eichner, E. R., Schnieder, S. M., and Young, A. J. (2000). Blood volume: importance and adaptations to exercise training, environmental stresses, and trauma/sickness. Med. Sci. Sports Exerc. 32, 332-348. doi: 10.1097/00005768-200002000-00012

Scaro, J. L. (1960). [Erythropoietic activity of urinary extracts of subjects living in high altitudes]. Rev. Soc. Argent Biol. 36, 1-8.

Schmidt, W., and Prommer, N. (2005). The optimised CO-rebreathing method: a new tool to determine total haemoglobin mass routinely. Eur. J. Appl. Physiol. 95, 486-495. doi: 10.1007/s00421-005-0050-3

Schmidt, W., and Prommer, N. (2008). Effects of various training modalities on blood volume. Scand. J. Med. Sci. Sports. 18 (Suppl. ), 1, 57-69. doi: 10.1111/j.1600-0838.2008.00833.x

Schmidt, W., and Prommer, N. (2010). Impact of alterations in total hemoglobin mass on $\mathrm{VO}_{2}$, max. Exerc. Sport Sci. Rev. 38, 68-75. doi: 10.1097/JES.0b013e3181d4957a

Schmidt, W., Eckardt, K. U., Hilgendorf, A., Strauch, S., and Bauer, C. (1991) Effects of maximal and submaximal exercise under normoxic and hypoxic conditions on serum erythropoietin level. Int. J. Sports Med. 12, 457-461. doi: 10.1055/s-2007-1024713

Schmidt, W., Maassen, N., Trost, F., and Böning, D. (1988). Training induced effects on blood volume, erythrocyte turnover and haemoglobin oxygen binding properties. Eur. J. Appl. Physiol. 57, 490-498. doi: 10.1007/BF00417998

Schobersberger, W., Tschann, M., Hasibeder, W., Steidl, M., Herold, M., Nachbauer, W., et al. (1990). Consequences of 6 weeks of strength training on red cell $\mathrm{O}_{2}$ transport and iron status. Eur. J. Appl. Physiol. Occup. Physiol. 60, 163-168. doi: 10.1007/BF00839152

Schofield, C. J., and Ratcliffe, P. J. (2004). Oxygen sensing by HIF hydroxylases. Nat. Rev. Mol. Cell Biol. 5, 343-354. doi: 10.1038/nrm 1366

Schumacher, Y. O., Jankovits, R., Bultermann, D., Schmid, A., and Berg, A. (2002). Hematological indices in elite cyclists. Scand. J. Med. Sci. Sports 12, 301-308. doi: 10.1034/j.1600-0838.2002.10112.x

Schwarz, A. J., Brasel, J. A., Hintz, R. L., Mohan, S., and Cooper, D. M. (1996). Acute effect of brief low- and high-intensity exercise on circulating insulin-like growth factor (IGF) I, II, and IGF-binding protein-3 and its proteolysis in young healthy men. J. Clin. Endocrinol. Metab. 81, 3492-3497. doi: 10.1210/jc.81.10.3492

Schwartz, K. A., and Flessa, H. C. (1973). March hemoglobinuria. Report of a case after basketball and congo drum playing. Ohio. State Med. J. 69, 448-449.

Scortegagna, M., Ding, K., Zhang, Q., Oktay, Y., Bennett, M. J., Bennett, M., et al. (2005). HIF-2alpha regulates murine hematopoietic development in an erythropoietin-dependent manner. Blood 105, 3133-3140. doi: 10.1182/blood2004-05-1695

Seamen, C., Wyss, S., and Piomelli, S. (1980). The decline in energetic metabolism with aging of the erythrocyte and its relationship to cell death. Am. J. Hematol. 8, 31-42. doi: 10.1002/ajh.2830080105

Selby, G. B., and Eichner, E. R. (1986). Endurance swimming, intravascular hemolysis, anemia, and iron depletion. New perspective on athlete's anemia. Am. J. Med. 81, 791-794. doi: 10.1016/0002-9343(86)90347-5

Semenza, G. L. (1999). Regulation of mammalian O2 homeostasis by hypoxia-inducible factor 1. Annu. Rev. Cell Dev. Biol. 15, 551-578. doi: 10.1146/annurev.cellbio.15.1.551

Semenza, G. L. (2009). Regulation of oxygen homeostasis by hypoxia-inducible factor 1. Physiology. (Bethesda.) 24, 97-106. doi: 10.1152/physiol.00045.2008

Severinghaus, J. W. (1979). Simple, accurate equations for human blood $\mathrm{O}_{2}$ dissociation computations. J. Appl. Physiol. 46/3, 599-602.

Shahani, S., Braga-Basaria, M., Maggio, M., and Basaria, S. (2009). Androgens and erythropoiesis: past and present. J. Endocrinol. Invest. 32, 704-716. doi: 10.3275/ 6149

Shahidi, N. T. (1973). Androgens and erythropoiesis. N. Engl. J. Med. 289, 72-80. doi: 10.1056/NEJM197307122890205

Sharpe, K., Hopkins, W., Emslie, K. R., Howe, C., Trout, G. J., Kazlauskas, R., et al. (2002). Development of reference ranges in elite athletes for markers of altered erythropoiesis. Haematologica 87, 1248-1257.

Shen, W., Zhang, X., Zhao, G., Wolin, M. S., Sessa, W., and Hintze, T. H. (1995). Nitric oxide production and NO synthase gene expression contribute to vascular regulation during exercise. Med. Sci. Sports Exerc. 27, 1125-1134. doi: 10.1249/00005768-199508000-00005 
Siebenmann, C., Robach, P., Jacobs, R. A., Rasmussen, P., Nordsborg, N., Diaz, V., et al. (2012). "“Live high-train low" " using normobaric hypoxia: a double-blinded, placebo-controlled study. J. Appl. Physiol. 112, 106-117. doi: 10.1152/japplphysiol.00388.2011

Simmonds, M. J., Connes, P., and Sabapathy, S. (2013). Exercise-induced blood lactate increase does not change red blood cell deformability in cyclists. PLoS. ONE. 8:e71219. doi: 10.1371/journal.pone.0071219

Siri, W. E., Van Dyke, D. C., Winchell, H. S., Pollycove, M., Parker, H. G., and Cleveland, A. S. (1966). Early erythropoietin, blood, and physiological responses to severe hypoxia in man. J. Appl. Physiol. 21, 73-80.

Sjostrand, T. (1948). A practical method for estimating carboxyhaemoglobin by alveolar air analysis. Overseas. Postgrad. Med. J. 2, 485-487.

Smith, J. A. (1995). Exercise, training and red blood cell turnover. Sports Med. 19, 9-31. doi: 10.2165/00007256-199519010-00002

Smith, M. M., Lucas, A. R., Hamlin, R. L., and Devor, S. T. (2013). Associations among hemorheological factors and maximal oxygen consumption. Is there a role for blood viscosity in explaining athletic performance? Clin. Hemorheol. Microcirc. doi: 10.3233/CH-131708. [Epub ahead of print]

Sprague, R. S., Ellsworth, M. L., Stephenson, A. H., and Lonigro, A. J. (1996). ATP: the red blood cell link to NO and local control of the pulmonary circulation. Am. J. Physiol. 271, H2717-H2722.

Sprague, R. S., Ellsworth, M. L., Stephenson, A. H., Kleinhenz, M. E., and Lonigro, A. J. (1998). Deformation-induced ATP release from red blood cells requires CFTR activity. Am. J. Physiol. Heart Circ. Physiol. 44, H1726-H1732.

Stamler, J. S., Jia, L., Eu, J. P., McMahon, T. J., Demchenko, I. T., Bonaventura, J., et al. (1997). Blood flow regulation by S-nitrosohemoglobin in the physiological oxygen gradient. Science 276, 2034-2037. doi: 10.1126/science.276.5321.2034

Stewart, I. B., and McKenzie, D. C. (2002). The human spleen during physiological stress. Sports Med. 32, 361-369. doi: 10.2165/00007256-200232060-00002

Stray-Gundersen, J., and Levine, B. D. (2008). Live high, train low at natural altitude. Scand. J. Med. Sci. Sports 18 (Suppl. ), 1, 21-28. doi: 10.1111/j.16000838.2008.00829.x

Streeton, J. A. (1967). Traumatic haemogloinuria caused by karate exercises. Lancet 2, 191-192. doi: 10.1016/S0140-6736(67)90010-4

Sun, X. G., Hansen, J. E., Ting, H., Chuang, M. L., Stringer, W. W., Adame, D., et al. (2000). Comparison of exercise cardiac output by the Fick principle using oxygen and carbon dioxide. Chest 118, 631-640. doi: 10.1378/chest.118.3.631

Sutera, S. P. (1977). Flow-induced trauma to blood cells. Circ. Res. 41, 2-8. doi: 10.1161/01.RES.41.1.2

Svedenhag, J., Piehl-Aulin, K., Skog, C., and Saltin, B. (1997). Increased left ventricular muscle mass after long-term altitude training in athletes. Acta Physiol Scand. 161, 63-70. doi: 10.1046/j.1365-201X.1997.00204.x

Telford, R. D., Sly, G. J., Hahn, A. G., Cunningham, R. B., Bryant, C., and Smith, J. A. (2003). Footstrike is the major cause of hemolysis during running. J Appl. Physiol. 94, 38-42.

Thirup, P. (2003). Haematocrit: within-subject and seasonal variation. Sports Med. 33, 231-243. doi: 10.2165/00007256-200333030-00005

Thomsen, J. K., Fogh-Andersen, N., Bülow, K., and Devantier, A. (1991). Blood and plasma volumes determined by carbon monoxide gas, ${ }^{99 m}$ Tc-labeled ery- throcytes, ${ }^{125} \mathrm{I}$-albumin and the T (1824). Technique. Scan. J. Clin. Lab. Invest. 51, 185-190. doi: 10.3109/00365519109091106

Ulker, P., Gunduz, F., Meiselman, H. J., and Baskurt, O. K. (2013). Nitric oxide generated by red blood cells following exposure to shear stress dilates isolated small mesenteric arteries under hypoxic conditions. Clin. Hemorheol. Microcirc. 54, 357-369. doi: 10.3233/CH-2012-1618

van der Brug, G. E., Peters, H. P., Hardeman, M. R., Schep, G., and Mosterd, W. L. (1995). Hemorheological response to prolonged exercise-no effects of different kinds of feedings. Int. J. Sports Med. 16, 231-237. doi: 10.1055/s-2007972997

Vandewalle, H., Lacombe, C., Lelievre, J. C., and Poirot, C. (1988). Blood viscosity after a 1-h submaximal exercise with and without drinking. Int. J. Sports Med. 9, 104-107. doi: 10.1055/s-2007-1024988

Vergouwen, P. C., Collee, T., and Marx, J. J. (1999). Haematocrit in elite athletes. Int. J. Sports Med. 20, 538-541. doi: 10.1055/s-1999-8842

Weber, R. E., and Fago, A. (2004). Functional adaptation and its molecular basis in vertebrate hemoglobins, neuroglobins and cytoglobins. Respir. Physiol. Neurobiol. 144, 141-159. doi: 10.1016/j.resp.2004.04.018

Weight, L. M., Alexander, D., Elliot, T., and Jacobs, P. (1992). Erythropoietic adaptations to endurance training. Eur. J. Appl. Physiol. Occup. Physiol. 64, 444-448. doi: 10.1007/BF00625065

Yalcin, O., Bor-Kucukatay, M., Senturk, U. K., and Baskurt, O. K. (2000). Effects of swimming exercise on red blood cell rheology in trained and untrained rats. J. Appl. Physiol. 88, 2074-2080.

Yoshimura, H., Inoue, T., Yamada, T., and Shiraki, K. (1980). Anemia during hard physical training (sports anemia) and its causal mechanism with special reference to protein nutrition. World Rev. Nutr. Diet 35, 1-86.

Zhao, J., Tian, Y., Cao, J., Jin, L., and Ji, L. (2013). Mechanism of endurance training-induced erythrocyte deformability in rats involves erythropoiesis. Clin. Hemorheol. Microcirc. 53, 257-266. doi: 10.3233/CH-2012-1549

Conflict of Interest Statement: The author declares that the research was conducted in the absence of any commercial or financial relationships that could be construed as a potential conflict of interest.

Received: 30 September 2013; accepted: 25 October 2013; published online: 12 November 2013.

Citation: Mairbäurl H (2013) Red blood cells in sports: effects of exercise and training on oxygen supply by red blood cells. Front. Physiol. 4:332. doi: 10.3389/fphys. 2013.00332

This article was submitted to Membrane Physiology and Membrane Biophysics, a section of the journal Frontiers in Physiology.

Copyright (c) 2013 Mairbäurl. This is an open-access article distributed under the terms of the Creative Commons Attribution License (CC BY). The use, distribution or reproduction in other forums is permitted, provided the original author(s) or licensor are credited and that the original publication in this journal is cited, in accordance with accepted academic practice. No use, distribution or reproduction is permitted which does not comply with these terms. 